\title{
Global inorganic nitrate production mechanisms: comparison of a global model with nitrate isotope observations
}

\author{
Becky Alexander $^{1}$, Tomás Sherwen ${ }^{2,3}$, Christopher D. Holmes ${ }^{4}$, Jenny A. Fisher ${ }^{5}$, Qianjie Chen ${ }^{1, a}$, Mat J. Evans ${ }^{2,3}$, \\ and Prasad Kasibhatla ${ }^{6}$ \\ ${ }^{1}$ Department of Atmospheric Sciences, University of Washington, Seattle, WA 98195, USA \\ ${ }^{2}$ Wolfson Atmospheric Chemistry Laboratories, Department of Chemistry, University of York, York YO10 5DD, UK \\ ${ }^{3}$ National Center for Atmospheric Science, University of York, York YO10 5DD, UK \\ ${ }^{4}$ Department of Earth, Ocean and Atmospheric Science, Florida State University, Tallahassee, FL 32306, USA \\ ${ }^{5}$ Centre for Atmospheric Chemistry, University of Wollongong, Wollongong, New South Wales 2522, Australia \\ ${ }^{6}$ Nicholas School of the Environment, Duke University, Durham, NC 27708, USA \\ ${ }^{a}$ now at: Department of Chemistry, University of Michigan, Ann Arbor, MI 48109, USA
}

Correspondence: Becky Alexander (beckya@uw.edu)

Received: 2 May 2019 - Discussion started: 8 May 2019

Revised: 15 February 2020 - Accepted: 17 February 2020 - Published: 31 March 2020

\begin{abstract}
The formation of inorganic nitrate is the main sink for nitrogen oxides $\left(\mathrm{NO}_{x}=\mathrm{NO}+\mathrm{NO}_{2}\right)$. Due to the importance of $\mathrm{NO}_{x}$ for the formation of tropospheric oxidants such as the hydroxyl radical $(\mathrm{OH})$ and ozone, understanding the mechanisms and rates of nitrate formation is paramount for our ability to predict the atmospheric lifetimes of most reduced trace gases in the atmosphere. The oxygen isotopic composition of nitrate $\left(\Delta^{17} \mathrm{O}\right.$ (nitrate) $)$ is determined by the relative importance of $\mathrm{NO}_{x}$ sinks and thus can provide an observational constraint for $\mathrm{NO}_{x}$ chemistry. Until recently, the ability to utilize $\Delta^{17} \mathrm{O}$ (nitrate) observations for this purpose was hindered by our lack of knowledge about the oxygen isotopic composition of ozone $\left(\Delta^{17} \mathrm{O}\left(\mathrm{O}_{3}\right)\right)$. Recent and spatially widespread observations of $\Delta^{17} \mathrm{O}\left(\mathrm{O}_{3}\right)$ motivate an updated comparison of modeled and observed $\Delta^{17} \mathrm{O}$ (nitrate) and a reassessment of modeled nitrate formation pathways. Model updates based on recent laboratory studies of heterogeneous reactions render dinitrogen pentoxide $\left(\mathrm{N}_{2} \mathrm{O}_{5}\right)$ hydrolysis as important as $\mathrm{NO}_{2}+\mathrm{OH}$ (both $41 \%$ ) for global inorganic nitrate production near the surface (below $1 \mathrm{~km}$ altitude). All other nitrate production mechanisms individually represent less than $6 \%$ of global nitrate production near the surface but can be dominant locally. Updated reaction rates for aerosol uptake of $\mathrm{NO}_{2}$ result in significant reduction of nitrate and nitrous acid (HONO) formed through this pathway in the model and render $\mathrm{NO}_{2}$ hydrolysis a negligible
\end{abstract}

pathway for nitrate formation globally. Although photolysis of aerosol nitrate may have implications for $\mathrm{NO}_{x}, \mathrm{HONO}$, and oxidant abundances, it does not significantly impact the relative importance of nitrate formation pathways. Modeled $\Delta{ }^{17} \mathrm{O}$ (nitrate) $(28.6 \pm 4.5 \%$ o $)$ compares well with the average of a global compilation of observations $(27.6 \pm 5.0 \%$ ) when assuming $\Delta^{17} \mathrm{O}\left(\mathrm{O}_{3}\right)=26 \%$, giving confidence in the model's representation of the relative importance of ozone versus $\mathrm{HO}_{x}\left(=\mathrm{OH}+\mathrm{HO}_{2}+\mathrm{RO}_{2}\right)$ in $\mathrm{NO}_{x}$ cycling and nitrate formation on the global scale.

\section{Introduction}

Nitrogen oxides $\left(\mathrm{NO}_{x}=\mathrm{NO}+\mathrm{NO}_{2}\right)$ are a critical ingredient for the formation of tropospheric ozone $\left(\mathrm{O}_{3}\right)$. Tropospheric ozone is a greenhouse gas, is a major precursor for the hydroxyl radical $(\mathrm{OH})$, and is considered an air pollutant due to its negative impacts on human health. The atmospheric lifetime of $\mathrm{NO}_{x}$ is determined by its oxidation to inorganic and organic nitrate. The formation of inorganic nitrate $\left(\mathrm{HNO}_{3}(\mathrm{~g})\right.$ and particulate $\mathrm{NO}_{3}^{-}$) is the dominant sink for $\mathrm{NO}_{x}$ globally, while formation of organic nitrate may be significant in rural and remote continental locations (Browne and Cohen, 2014). Organic nitrate as a sink for $\mathrm{NO}_{x}$ may be becoming more important in regions in North America and Europe where $\mathrm{NO}_{x}$ 
emissions have declined (Zare et al., 2018). Uncertainties in the rate of oxidation of $\mathrm{NO}_{x}$ to nitrate have been shown to represent a significant source of uncertainty for ozone and OH formation in models (e.g., Newsome and Evans, 2017), with implications for our understanding of the atmospheric lifetime of species such as methane, whose main sink is reaction with $\mathrm{OH}$.

$\mathrm{NO}_{x}$ is emitted to the atmosphere primarily as NO by fossil fuel and biomass/biofuel burning, soil microbes, and lightning. Anthropogenic sources from fossil fuel and biofuel burning and from the application of fertilizers to soil for agriculture currently dominate $\mathrm{NO}_{x}$ sources to the atmosphere (Jaeglé et al., 2005). After emission, NO is rapidly oxidized to $\mathrm{NO}_{2}$ by ozone $\left(\mathrm{O}_{3}\right)$, peroxy $\left(\mathrm{HO}_{2}\right)$ and hydroperoxy radicals $\left(\mathrm{RO}_{2}\right)$, and halogen oxides (e.g., $\left.\mathrm{BrO}\right)$. During the daytime, $\mathrm{NO}_{2}$ is rapidly photolyzed to $\mathrm{NO}+\mathrm{O}$ at wavelengths $(\lambda)<398 \mathrm{~nm}$. $\mathrm{NO}_{x}$ cycling between $\mathrm{NO}$ and $\mathrm{NO}_{2}$ proceeds several orders of magnitude faster than oxidation of $\mathrm{NO}_{x}$ to nitrate during the daytime (Michalski et al., 2003).

Formation of inorganic nitrate is dominated by oxidation of $\mathrm{NO}_{2}$ by $\mathrm{OH}$ during the day and by the hydrolysis of dinitrogen pentoxide $\left(\mathrm{N}_{2} \mathrm{O}_{5}\right)$ at night (Alexander et al., 2009). Recent implementations of reactive halogen chemistry in models of tropospheric chemistry show that formation of nitrate from the hydrolysis of halogen nitrates $\left(\mathrm{XNO}_{3}\right.$, where $\mathrm{X}=\mathrm{Br}, \mathrm{Cl}$, or I) is also a sink for $\mathrm{NO}_{x}$ with implications for tropospheric ozone, $\mathrm{OH}$, reactive halogens, and aerosol formation (Schmidt et al., 2016; Sherwen et al., 2016; Saiz-Lopez et al., 2012; Long et al., 2014; Parrella et al., 2012; von Glasow and Crutzen, 2004; Yang et al., 2005). Other inorganic nitrate formation pathways include hydrogen abstraction of hydrocarbons by the nitrate radical $\left(\mathrm{NO}_{3}\right)$, heterogeneous reaction of $\mathrm{N}_{2} \mathrm{O}_{5}$ with particulate chloride $\left(\mathrm{Cl}^{-}\right)$, heterogeneous uptake of $\mathrm{NO}_{2}$ and $\mathrm{NO}_{3}$, direct oxidation of $\mathrm{NO}$ to $\mathrm{HNO}_{3}$ by $\mathrm{HO}_{2}$, and hydrolysis of organic nitrate (Atkinson, 2000). Inorganic nitrate partitions between the gas $\left(\mathrm{HNO}_{3}(\mathrm{~g})\right)$ and particle $\left(\mathrm{NO}_{3}^{-}\right)$phases, with its relative partitioning dependent upon aerosol abundance, aerosol liquid water content, aerosol chemical composition, and temperature. Inorganic nitrate is lost from the atmosphere through wet or dry deposition to the Earth's surface with a global lifetime against deposition on the order of 3-4 d (Park et al., 2004).

Formation of inorganic nitrate was thought to be a permanent sink for $\mathrm{NO}_{x}$ in the troposphere due to the slow photolysis of nitrate compared to deposition. However, laboratory and field studies have shown that $\mathrm{NO}_{3}^{-}$adsorbed on surfaces is photolyzed at rates much higher than $\mathrm{HNO}_{3}(\mathrm{~g}$ ) (Ye et al., 2016). For example, the photolysis of $\mathrm{NO}_{3}^{-}$in snow grains on ice sheets has a profound impact on the oxidizing capacity of the polar atmosphere (Domine and Shepson, 2002). More recently, observations of $\mathrm{NO}_{x}$ and nitrous acid (HONO) provide evidence of photolysis of aerosol $\mathrm{NO}_{3}^{-}$in the marine (Reed et al., 2017; Ye et al., 2016) and continental (Ye et al.,
2018; Chen et al., 2019) boundary layer, with implications for ozone and $\mathrm{OH}$ (Kasibhatla et al., 2018).

Organic nitrates form during reaction of $\mathrm{NO}_{x}$ and $\mathrm{NO}_{3}$ with biogenic volatile organic compounds (BVOCs) and their oxidation products (organic peroxy radicals, $\mathrm{RO}_{2}$ ) (Browne and Cohen, 2014; Liang et al., 1998). Products of these reactions include peroxy nitrates $\left(\mathrm{RO}_{2} \mathrm{NO}_{2}\right)$ and alkyl and multifunctional nitrates $\left(\mathrm{RONO}_{2}\right)\left(\mathrm{O}^{\prime} \mathrm{Brien}\right.$ et al., 1995). Peroxy nitrates are thermally unstable and decompose back to $\mathrm{NO}_{x}$ on the order of minutes to days at warm temperatures. Decomposition of longer-lived peroxy nitrates such as peroxyacetyl nitrate (PAN) can provide a source of $\mathrm{NO}_{x}$ to remote environments (Singh et al., 1992). The fate of $\mathrm{RONO}_{2}$ is uncertain. First-generation $\mathrm{RONO}_{2}$ is oxidized to form secondgeneration $\mathrm{RONO}_{2}$ species with a lifetime of about a week for the first-generation species with $\geq 4$ carbon atoms and up to several weeks for species with fewer carbon atoms (e.g., days to weeks for methyl nitrate) (Fisher et al., 2018). Subsequent photolysis and oxidation of second-generation $\mathrm{RONO}_{2}$ species can lead to the recycling of $\mathrm{NO}_{x}$ (Müller et al., 2014), although recycling efficiencies are highly uncertain (Horowitz et al., 2007; Paulot et al., 2009). $\mathrm{RONO}_{2}$ can also partition to the particle phase $\left(p \mathrm{RONO}_{2}\right)$ contributing to organic aerosol formation (Xu et al., 2015). $p \mathrm{RONO}_{2}$ is removed from the atmosphere by deposition to the surface or through hydrolysis to form inorganic nitrate and alcohols (Rindelaub et al., 2015; Jacobs et al., 2014).

The oxygen isotopic composition $\left(\Delta^{17} \mathrm{O}=\delta^{17}-0.52 \times\right.$ $\delta^{18} \mathrm{O}$ ) of nitrate is determined by the relative importance of oxidants leading to nitrate formation from the oxidation of $\mathrm{NO}_{x}$ (Michalski et al., 2003). Observations of the oxygen isotopic composition of nitrate $\left(\Delta^{17} \mathrm{O}(\right.$ nitrate $\left.)\right)$ have been used to quantify the relative importance of different nitrate formation pathways and to assess model representation of the chemistry of nitrate formation in the present day (Alexander et al., 2009; Michalski et al., 2003; Costa et al., 2011; Ishino et al., 2017; Morin et al., 2009, 2008, 2007; Savarino et al., 2007, 2013; Kunasek et al., 2008; McCabe et al., 2007; Hastings et al., 2003; Kaiser et al., 2007; Brothers et al., 2008; Ewing et al., 2007) and in the past from nitrate archived in ice cores (Sofen et al., 2014; Alexander et al., 2004; Geng et al., 2014, 2017). Ozone-influenced reactions in $\mathrm{NO}_{x}$ oxidation lead to high $\Delta^{17} \mathrm{O}$ (nitrate) values while $\mathrm{HO}_{x}$-influenced reactions lead to $\Delta^{17} \mathrm{O}$ (nitrate) near zero. Oxidation by $\mathrm{XO}$ (where $\mathrm{X}=\mathrm{Br}, \mathrm{Cl}$, or I) leads to $\Delta^{17} \mathrm{O}$ (nitrate) values similar to reactions with ozone because the oxygen atom in $\mathrm{XO}$ is derived from the reaction $X+\mathrm{O}_{3}$. Therefore, $\Delta^{17} \mathrm{O}$ (nitrate) is determined by the relative importance of $\mathrm{O}_{3}+\mathrm{XO}$ versus $\mathrm{HO}_{x}\left(=\mathrm{OH}+\mathrm{HO}_{2}+\mathrm{RO}_{2}\right)$ in both $\mathrm{NO}_{x}$ cycling and oxidation to nitrate. Although freshly emitted $\mathrm{NO}$ will have $\Delta^{17} \mathrm{O}(\mathrm{NO})=0 \%, \mathrm{NO}_{x}$ achieves isotopic equilibrium during the daytime due to rapid $\mathrm{NO}_{x}$ cycling, so that its $\Delta^{17} \mathrm{O}$ value $\left(\Delta^{17} \mathrm{O}\left(\mathrm{NO}_{x}\right)\right)$ is solely determined by the relative abundance of $\left(\mathrm{O}_{3}+\mathrm{XO}\right)$ to $\left(\mathrm{HO}_{2}+\mathrm{RO}_{2}\right)$ (Michalski et al., 2003). 
The $\Delta^{17} \mathrm{O}$ value of $\mathrm{HO}_{x}\left(\Delta^{17} \mathrm{O}\left(\mathrm{HO}_{x}\right)\right)$ is near zero due to isotopic exchange of $\mathrm{OH}$ with water vapor (Dubey et al., 1997). Previously, observations of the $\Delta^{17} \mathrm{O}$ value of ozone $\left(\Delta^{17} \mathrm{O}\left(\mathrm{O}_{3}\right)\right)$ showed a large range $\left(6 \% \%_{-}-54 \%\right.$ ) (Johnston and Thiemens, 1997; Krankowsky et al., 1995), in contrast to laboratory and modeling studies suggesting that the range of $\Delta^{17} \mathrm{O}\left(\mathrm{O}_{3}\right)$ in the troposphere should be relatively narrow (30\%-46\%o) (Morton et al., 1990; Thiemens, 1990). The large range of observed $\Delta^{17} \mathrm{O}\left(\mathrm{O}_{3}\right)$ values is thought to be due to sampling artifacts (Brenninkmeijer et al., 2003). Uncertainty in the value of $\Delta^{17} \mathrm{O}\left(\mathrm{O}_{3}\right)$ has been the largest source of uncertainty in quantification of nitrate formation pathways using observations of $\Delta^{17} \mathrm{O}$ (nitrate) (Alexander et al., 2009). Previous modeling studies showed good agreement with observations of $\Delta^{17} \mathrm{O}$ (nitrate) when assuming that the bulk oxygen isotopic composition of ozone $\left(\Delta^{17} \mathrm{O}\left(\mathrm{O}_{3}\right)\right)$ is equal to 35\%o (Alexander et al., 2009; Michalski et al., 2003) but varied in their assumption on terminal oxygen atom versus statistical isotopic transfer from $\mathrm{O}_{3}$ to the reactant ( $\mathrm{NO}$ and $\mathrm{NO}_{2}$ ). This is an important distinction because it is now known that the ${ }^{17} \mathrm{O}$ enrichment in $\mathrm{O}_{3}$ is contained entirely in its terminal oxygen atoms, and it is the terminal oxygen atom that is transferred from $\mathrm{O}_{3}$ (Vicars et al., 2012; Berhanu et al., 2012; Bhattacharya et al., 2008, 2014; Savarino et al., 2008; Michalski and Bhattacharya, 2009), so that the $\Delta^{17} \mathrm{O}$ value of the oxygen atom transferred from ozone to the product is $50 \%$ larger than the bulk $\Delta{ }^{17} \mathrm{O}\left(\mathrm{O}_{3}\right)$ value. Recently, much more extensive observations of $\Delta^{17} \mathrm{O}\left(\mathrm{O}_{3}\right)$ using a new technique (Vicars et al., 2012) consistently show $\Delta^{17} \mathrm{O}\left(\mathrm{O}_{3}\right)=26 \pm 1 \%$ in diverse locations (Vicars et al., 2012; Ishino et al., 2017; Vicars and Savarino, 2014) and suggest that previous modeling studies are biased low in $\Delta^{17} \mathrm{O}$ (nitrate) (e.g., Alexander et al. 2009), which would occur if the model underestimated the relative role of ozone in $\mathrm{NO}_{x}$ chemistry. These new observations of $\Delta^{17} \mathrm{O}\left(\mathrm{O}_{3}\right)$, combined with improved understanding and hence more comprehensive chemical representation of nitrate formation in models, motivate an updated comparison of observed and modeled $\Delta^{17} \mathrm{O}$ (nitrate) as an observational constraint for the relative importance of nitrate formation pathways in the atmosphere. Note that laboratory studies show that the magnitude of $\Delta^{17} \mathrm{O}\left(\mathrm{O}_{3}\right)$ is dependent on temperature and pressure (Heidenreich and Thiemens, 1986; Thiemens, 1990; Morton et al., 1990). The observations of $\Delta^{17} \mathrm{O}\left(\mathrm{O}_{3}\right)$ by Vicars et al. $(2012,2013)$ were at the surface over a large temperature range but may not reflect the value of $\Delta^{17} \mathrm{O}\left(\mathrm{O}_{3}\right)$ at higher altitudes. However, with the exception of lightning, whose emissions are presently several times smaller than $\mathrm{NO}_{x}$ emissions from anthropogenic and biomass burning sources (Murray, 2016), $\mathrm{NO}_{x}$ sources emit at the surface. With a $\mathrm{NO}_{x}$ lifetime relative to its conversion to nitrate on the order of $1 \mathrm{~d}$ (Levy et al., 1999), most nitrate formation also occurs near the surface. Here, we examine the relative contribution of each nitrate formation pathway in a global chemical transport model and compare the model with surface observations of $\Delta^{17} \mathrm{O}$ (nitrate) from around the world.

\section{Methods}

We use the GEOS-Chem global chemical transport model version 12.0.0 driven by assimilated meteorology from the MERRA-2 reanalysis product with a native resolution of $0.5^{\circ} \times 0.625^{\circ}$ and 72 vertical levels from the surface up to the $0.01 \mathrm{hPa}$ pressure level. For computational expediency, the horizontal and vertical resolution were downgraded to $4^{\circ} \times 5^{\circ}$ and 47 vertical levels. GEOS-Chem was originally described in Bey et al. (2001) and includes coupled $\mathrm{HO}_{x}-\mathrm{NO}_{x}-\mathrm{VOC}-$ ozone-halogen-aerosol tropospheric chemistry as described in Sherwen et al. $(2016,2017)$ and organic nitrate chemistry as described in Fisher et al. (2016). Aerosols interact with gas-phase chemistry through the effect of aerosol extinction on photolysis rates (Martin et al., 2003) and heterogeneous chemistry (Jacob, 2000). The model calculates deposition for both gas species and aerosols (Liu et al., 2001; Zhang et al., 2001; Wang et al., 1998).

Global anthropogenic emissions, including $\mathrm{NO}_{x}$, are from the Community Emissions Data System (CEDS) inventory from 1950 to $2014 \mathrm{CE}$ (Hoesly et al., 2018). The CEDS global emissions inventory is overwritten by regional anthropogenic emissions inventories in the US (EPA/NE11), Canada (CAC), Europe (EMEP), and Asia (MIX Li et al., 2017). Global shipping emissions are from the International Comprehensive Ocean-Atmosphere Data Set (ICOADS), which was implemented into GEOS-Chem as described in Lee et al. (2011). $\mathrm{NO}_{x}$ emissions from ships are processed using the PARANOX module described in Vinken et al. (2011) and Holmes et al. (2014) to account for nonlinear, in-plume ozone and $\mathrm{HNO}_{3}$ production. Lightning $\mathrm{NO}_{x}$ emissions match the OTD/LIS satellite climatological observations of lightning flashes as described by Murray et al. (2012). Emissions from open fires are from the Global Fire Emissions Database (GFED4.1). Biogenic soil $\mathrm{NO}_{x}$ emissions are described in Hudman et al. (2012). Aircraft emissions are from the Aviation Emissions Inventory Code (AEIC) (Stettler et al., 2011).

Chemical processes leading to nitrate formation in GEOSChem have expanded since the previous work of Alexander et al. (2009). Figure 1 summarizes the formation of inorganic nitrate in the current model. In the model, $\mathrm{NO}$ is oxidized by $\mathrm{O}_{3}, \mathrm{HO}_{2}, \mathrm{RO}_{2}$, and halogen oxides $(\mathrm{XO}=\mathrm{BrO}, \mathrm{ClO}, \mathrm{IO}$, and OIO) to form $\mathrm{NO}_{2}$. The reaction of $\mathrm{NO}+\mathrm{HO}_{2}$ can also form $\mathrm{HNO}_{3}$ directly, although the branching ratio for this pathway is $<1 \%$ (Butkovskaya et al., 2005). $\mathrm{NO}_{2}$ can form $\mathrm{HNO}_{3}$ directly from its reaction with $\mathrm{OH}$ and through hydrolysis on aerosol surfaces. $\mathrm{NO}_{2}$ can react with $\mathrm{XO}$ to form halogen nitrates $\left(\mathrm{BrNO}_{3}, \mathrm{ClNO}_{3}\right.$, and $\left.\mathrm{INO}_{3}\right)$, which can then form $\mathrm{HNO}_{3}$ upon hydrolysis (as described in Sherwen et al., 2016). $\mathrm{NO}_{2}$ can also react with $\mathrm{O}_{3}$ to form $\mathrm{NO}_{3}$, which can 


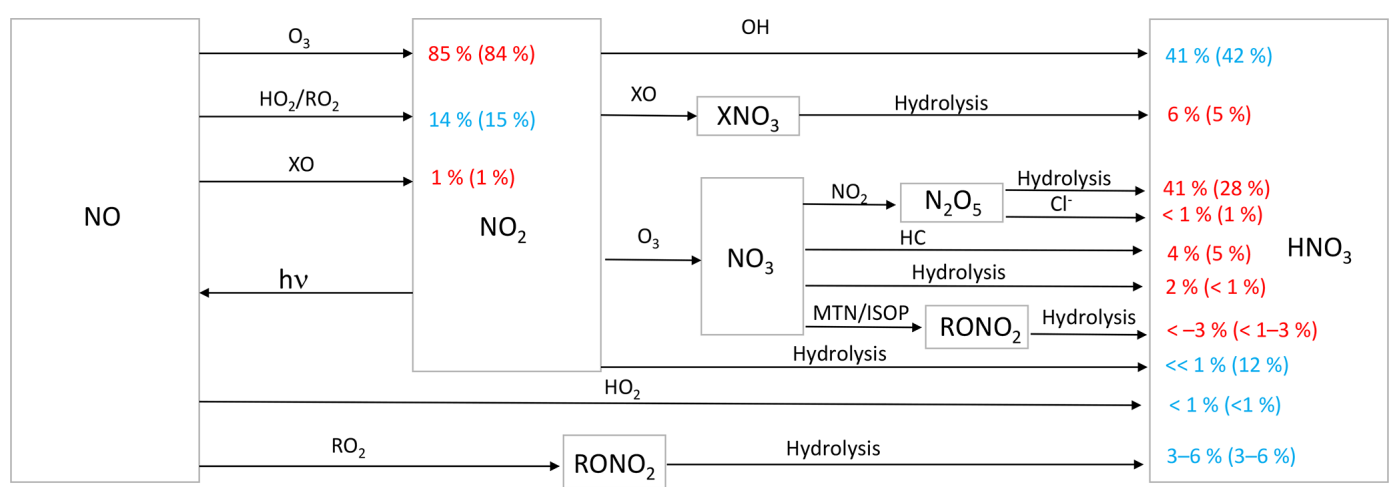

Figure 1. Simplified $\mathrm{HNO}_{3}$ formation in the model. Numbers show the global annual-mean percent contribution to $\mathrm{NO}_{2}$ and $\mathrm{HNO}_{3}$ formation in the troposphere below $1 \mathrm{~km}$ for the cloud chemistry (standard) simulation. Red indicates reactions leading to high $\Delta^{17} \mathrm{O}$ values, and blue indicates reactions leading to low $\Delta^{17} \mathrm{O}$ values. $\mathrm{HO}_{2}=\mathrm{HO}_{2}+\mathrm{RO}_{2} ; \mathrm{X}=\mathrm{Br}+\mathrm{Cl}+\mathrm{I}$; HC: hydrocarbons; MTN: monoterpenes; ISOP: isoprene.

then react with $\mathrm{NO}_{2}$, hydrocarbons (HC), and the biogenic VOC monoterpenes (MTN) and isoprene (ISOP). Reaction of $\mathrm{NO}_{3}$ with $\mathrm{NO}_{2}$ forms $\mathrm{N}_{2} \mathrm{O}_{5}$, which can subsequently hydrolyze or react with $\mathrm{Cl}^{-}$in aerosol to form $\mathrm{HNO}_{3}$. Reaction of $\mathrm{NO}_{3}$ with $\mathrm{HC}$ forms $\mathrm{HNO}_{3}$ via hydrogen abstraction. Reactions of $\mathrm{NO}_{3}$ are only important at night due to its short lifetime against photolysis. Formation of organic nitrate $\left(\mathrm{RONO}_{2}\right)$ was recently updated in the model as described in Fisher et al. (2016). Reaction of $\mathrm{NO}_{3}$ with MTN and ISOP can form $\mathrm{RONO}_{2} . \mathrm{RONO}_{2}$ also forms from the reaction of $\mathrm{NO}$ with $\mathrm{RO}_{2}$ derived from $\mathrm{OH}$ oxidation of BVOCs. $\mathrm{RONO}_{2}$ hydrolyzes to form $\mathrm{HNO}_{3}$ on a timescale of $1 \mathrm{~h}$. Inorganic nitrate partitions between the gas $\left(\mathrm{HNO}_{3}(\mathrm{~g})\right)$ and particle $\left(\mathrm{NO}_{3}^{-}\right)$phase according to local thermodynamic equilibrium as calculated in the ISORROPIA-II aerosol thermodynamic module (Fountoukis and Nenes, 2007). $\mathrm{HNO}_{3}(\mathrm{~g})$ and $\mathrm{NO}_{3}^{-}$are mainly lost from the atmosphere via wet and dry deposition to the surface.

In the standard model, hydrolysis of $\mathrm{N}_{2} \mathrm{O}_{5}, \mathrm{NO}_{3}$ $\left(\gamma_{\mathrm{NO}_{3}}=1 \times 10^{-3}\right)$, and $\mathrm{NO}_{2}\left(\gamma_{\mathrm{NO}_{2}}=1 \times 10^{-4}\right)$ occurs on aerosol surfaces only. Uptake and hydrolysis of $\mathrm{N}_{2} \mathrm{O}_{5}$ on aerosol surfaces depend on the chemical composition of aerosols, temperature, and humidity as described in Evans and Jacob (2005). Recently, Holmes et al. (2019) updated the reaction probabilities of the $\mathrm{NO}_{2}$ and $\mathrm{NO}_{3}$ heterogeneous reactions in the model to depend on aerosol chemical composition and relative humidity. Holmes et al. (2019) also updated the $\mathrm{N}_{2} \mathrm{O}_{5}$ reaction probability to additionally depend on the $\mathrm{H}_{2} \mathrm{O}$ and $\mathrm{NO}_{3}^{-}$concentrations in aerosol (Bertram and Thornton, 2009). In addition to these updates for hydrolysis on aerosol, Holmes et al. (2019) included the uptake and hydrolysis of $\mathrm{N}_{2} \mathrm{O}_{5}, \mathrm{NO}_{2}$, and $\mathrm{NO}_{3}$ in cloud water and ice limited by cloud entrainment rates. We incorporate these updates from Holmes et al. (2019) into the cloud chemistry model to examine the impacts on global nitrate production mechanisms. We consider the cloud chemistry model as state of the science, and as such we focus on the results of this par- ticular simulation. Additional model sensitivity studies are also performed and examined relative to the standard model simulation, which represents a more common representation of nitrate chemistry in atmospheric chemistry models. These additional sensitivity simulations are described in Sect. 4 .

$\Delta{ }^{17} \mathrm{O}$ (nitrate) is calculated in the model using monthlymean, local chemical production rates rather than by treating different isotopic combinations of nitrate as separate tracers that can be transported in the model. Alexander et al. (2009) transported four nitrate tracers, one each for nitrate production by $\mathrm{NO}_{2}+\mathrm{OH}, \mathrm{N}_{2} \mathrm{O}_{5}$ hydrolysis, $\mathrm{NO}_{3}+\mathrm{HC}$, and nitrate originating from its formation in the stratosphere. Since $\Delta^{17} \mathrm{O}\left(\mathrm{NO}_{x}\right)$ was not transported in the Alexander et al. (2009) model, it was calculated using local production rates, so effectively only one-third of the $\Delta^{17} \mathrm{O}$ (nitrate) was transported in Alexander et al. (2009). Accurately accounting for transport of $\Delta^{17} \mathrm{O}$ (nitrate) in the model would require transporting all individual isotopic combinations of the primary reactant (NO), the final product (nitrate), and each reaction intermediate (e.g., $\mathrm{N}_{2} \mathrm{O}_{5}$ ), which we do not do here due to the large computational costs. Thus, the model results shown here represent $\Delta^{17} \mathrm{O}$ (nitrate) from local $\mathrm{NO}_{x}$ cycling and nitrate production. This may lead to model biases, particularly in remote regions such as polar regions in wintertime when most nitrate is likely transported from lower latitudes or the stratosphere. This should make less of a difference in polluted regions where most nitrate is formed locally or for example in polar regions in summer when photochemical recycling of nitrate in the snowpack represents a significant local source of $\mathrm{NO}_{x}$ at the surface (Domine and Shepson, 2002). Although lack of transport of the isotope tracers adds uncertainty to direct comparison of the model with observations at any particular location, this approach will reflect the full range of possible modeled $\Delta^{17} \mathrm{O}$ (nitrate) values for the current chemical mechanism, which can then be compared to the range of observed $\Delta^{17} \mathrm{O}$ (nitrate) values around the globe. 
Table 1. Calculated $\Delta^{17} \mathrm{O}$ (nitrate) in the model for each nitrate production pathway $(\mathrm{X}=\mathrm{Br}$, $\mathrm{Cl}$, and I; HC: hydrocarbon; MTN: monoterpenes; ISOP: isoprene; $\Delta^{17} \mathrm{O}\left(\mathrm{O}_{3}^{*}\right)=39 \%$ ). $A$ is defined in Eq. (1).

\begin{tabular}{|c|c|c|}
\hline & Nitrate formation pathway & $\Delta \Delta^{17} \mathrm{O}$ (nitrate) \\
\hline & \multicolumn{2}{|l|}{ Gas-phase reactions } \\
\hline R1 & $\mathrm{NO}_{2}+\mathrm{OH}$ & $2 / 3 A \Delta^{17} \mathrm{O}\left(\mathrm{O}_{3}^{*}\right)$ \\
\hline R2 & $\mathrm{NO}_{3}+\mathrm{HC}$ & $(2 / 3 A+1 / 3) \Delta^{17} \mathrm{O}\left(\mathrm{O}_{3}^{*}\right)$ \\
\hline \multirow[t]{2}{*}{ R3 } & $\mathrm{NO}+\mathrm{HO}_{2}$ & $1 / 3 A \Delta^{17} \mathrm{O}\left(\mathrm{O}_{3}^{*}\right)$ \\
\hline & \multicolumn{2}{|c|}{ Aerosol uptake from the gas phase followed by hydrolysis } \\
\hline R4 & $\mathrm{N}_{2} \mathrm{O}_{5}+\mathrm{H}_{2} \mathrm{O}_{(\mathrm{aq})}$ & $(2 / 3 A+1 / 6) \Delta^{17} \mathrm{O}\left(\mathrm{O}_{3}^{*}\right)$ \\
\hline R5 & $\mathrm{N}_{2} \mathrm{O}_{5}+\mathrm{Cl}^{-}(\mathrm{aq})$ & $(2 / 3 A+1 / 3) \Delta \Delta^{17} \mathrm{O}\left(\mathrm{O}_{3}^{*}\right)$ \\
\hline R6 & $\mathrm{XNO}_{3}+\mathrm{H}_{2} \mathrm{O}_{(\mathrm{aq})}$ & $(2 / 3 A+1 / 3) \Delta^{17} \mathrm{O}\left(\mathrm{O}_{3}^{*}\right)$ \\
\hline R7 & $\mathrm{NO}_{2}+\mathrm{H}_{2} \mathrm{O}_{(\mathrm{aq})}$ & $(2 / 3 A+1 / 3) \Delta^{17} \mathrm{O}\left(\mathrm{O}_{3}^{*}\right)$ \\
\hline R8 & $\mathrm{NO}_{3}+\mathrm{H}_{2} \mathrm{O}_{(\mathrm{aq})}$ & $(2 / 3 A+1 / 3) \Delta^{17} \mathrm{O}\left(\mathrm{O}_{3}^{*}\right)$ \\
\hline R9 & $\begin{array}{l}\mathrm{RONO}_{2}+\mathrm{H}_{2} \mathrm{O}_{(\mathrm{aq})} \\
\left(\text { where } \mathrm{RONO}_{2} \text { is from } \mathrm{NO}+\mathrm{RO}_{2} \text { ) }\right.\end{array}$ & $1 / 3 A \Delta^{17} \mathrm{O}\left(\mathrm{O}_{3}^{*}\right)$ \\
\hline R10 & $\begin{array}{l}\mathrm{RONO}_{2}+\mathrm{H}_{2} \mathrm{O}_{(\mathrm{aq})} \\
\left.\text { (where } \mathrm{RONO}_{2} \text { is from } \mathrm{NO}_{3}+\mathrm{MTN} / \mathrm{ISOP}\right)\end{array}$ & $(2 / 3 A+1 / 3) \Delta^{17} \mathrm{O}\left(\mathrm{O}_{3}^{*}\right)$ \\
\hline
\end{tabular}

The $\Delta^{17} \mathrm{O}$ (nitrate) value of nitrate produced from each production pathway is calculated as shown in Table 1. The value of $A$ in Table 1 represents the relative importance of the oxidation pathways of $\mathrm{NO}$ to $\mathrm{NO}_{2}$ where the oxygen atom transferred comes from ozone $\left(\mathrm{NO}+\mathrm{O}_{3}\right.$ and $\left.\mathrm{NO}+\mathrm{XO}\right)$ :

$A=$

$\frac{k_{\mathrm{O}_{3}+\mathrm{NO}}\left[\mathrm{O}_{3}\right]+k_{\mathrm{XO}+\mathrm{NO}}[\mathrm{XO}]}{k_{\mathrm{O}_{3}+\mathrm{NO}}\left[\mathrm{O}_{3}\right]+k_{\mathrm{XO}+\mathrm{NO}}[\mathrm{XO}]+k_{\mathrm{HO}_{2}+\mathrm{NO}}\left[\mathrm{HO}_{2}\right]+k_{\mathrm{RO}_{2}+\mathrm{NO}}\left[\mathrm{RO}_{2}\right]}$.

In Eq. (1), $k$ represents the local reaction rate constant for each of the four reactions, $\mathrm{XO}=\mathrm{BrO}, \mathrm{ClO}, \mathrm{IO}$, and $\mathrm{OIO}$; and we assume $\Delta^{17} \mathrm{O}(\mathrm{XO})$ is equal to the $\Delta^{17} \mathrm{O}$ value of the terminal oxygen atoms of ozone, as described in more detail below. This effectively assumes that the other oxidation pathways $\left(\mathrm{NO}+\mathrm{HO}_{2}\right.$ and $\left.\mathrm{NO}+\mathrm{RO}_{2}\right)$ yield $\Delta{ }^{17} \mathrm{O}\left(\mathrm{NO}_{x}\right)=0 \%$. Although $\mathrm{HO}_{2}$ may have a small ${ }^{17} \mathrm{O}$ enrichment on the order of 1\%o-2\%o (Savarino and Thiemens, 1999b), the assumption that this pathway yields $\Delta^{17} \mathrm{O}\left(\mathrm{NO}_{x}\right)=0 \%$ simplifies the calculation and leads to negligible differences in calculated $\Delta^{17} \mathrm{O}$ (nitrate) (Michalski et al., 2003). This approach assumes that $\mathrm{NO}_{x}$ cycling is in a photochemical steady state, which only occurs during the daytime. $A$ is calculated in the model as the $24 \mathrm{~h}$ average $\mathrm{NO}_{2}$ production rate rather than the daytime average only. As was shown in Alexander et al. (2009), rapid daytime $\mathrm{NO}_{x}$ cycling dominates the calculated $24 \mathrm{~h}$ averaged $A$ value, leading to negligible differences in calculated $\Delta^{17} \mathrm{O}$ (nitrate) for $24 \mathrm{~h}$ averaged values versus daytime averaged values.

$\mathrm{NO}_{x}$ formed during the day will retain its daytime $\Delta^{17} \mathrm{O}\left(\mathrm{NO}_{x}\right)$ signature throughout the night due to lack of $\mathrm{NO}_{2}$ photolysis (Morin et al., 2011), suggesting similar $A$ values for the nighttime reactions (R2, R4, R5, R8, and R10 in Table 1). However, NO emitted at night will not undergo photochemical recycling, initially suggesting that NO will retain its emitted $\Delta^{17} \mathrm{O}(\mathrm{NO})$ value of $0 \%$ prior to sunrise. Thus, any $\mathrm{NO}$ emitted at night and oxidized to $\mathrm{NO}_{2}$ before sunrise will result in $\Delta^{17} \mathrm{O}\left(\mathrm{NO}_{2}\right)$ equal to one-half of the $\Delta{ }^{17} \mathrm{O}$ value of the oxidant, since only one of the two oxygen atoms of $\mathrm{NO}_{2}$ will originate from the oxidant. Since $\mathrm{HO}_{x}$ abundance is low at night, ozone will be the dominant oxidant. Thus, $\mathrm{NO}$ both emitted and oxidized to $\mathrm{NO}_{2}$ at night will lead to $A_{\text {night }}=0.5$ (half of the $\mathrm{O}$ atoms of $\mathrm{NO}_{2}$ originate from $\mathrm{O}_{3}$ ). Although isotopic exchange between $\mathrm{NO}+\mathrm{NO}_{2}$ (Sharma et al., 1970) and $\mathrm{NO}_{2}$ and $\mathrm{NO}_{3}$ via thermal dissociation of $\mathrm{N}_{2} \mathrm{O}_{5}$ (Connell and Johnston, 1979) will tend to increase $\Delta^{17} \mathrm{O}(\mathrm{NO})$ above its emitted value of $0 \%$, the bulk $\Delta{ }^{17} \mathrm{O}$ value of the $\mathrm{NO}_{x}$ plus $\mathrm{NO}_{3}$ system will be lower at night than during the daytime due to the absence of photochemical cycling at night (Michalski et al., 2014; Morin et al., 2011). Since the atmospheric lifetime of $\mathrm{NO}_{x}$ near the surface against nighttime oxidation to nitrate $(\mathrm{R} 2+\mathrm{R} 4+\mathrm{R} 5)$ is typically greater than $24 \mathrm{~h}$ (Fig. S1 in the Supplement), most nitrate formed during the nighttime will form from $\mathrm{NO}_{x}$ that reached photochemical equilibrium during the previous day. Thus, we use values of $A$ calculated as the $24 \mathrm{~h}$ average $\mathrm{NO}_{2}$ production rate for calculating the $\Delta^{17} \mathrm{O}$ (nitrate) value of all nitrate production pathways, including those that can occur at night. Using $24 \mathrm{~h}$ averaged $A$ values may lead to an overestimate of $\Delta^{17} \mathrm{O}$ (nitrate) in locations with more rapid nighttime nitrate formation rates such as in China and India (Fig. S1). However, even in these locations the lifetime of $\mathrm{NO}_{x}$ against nighttime oxidation is greater than $12 \mathrm{~h}$, suggesting that over half of nitrate formation at night occurs from the oxidation of $\mathrm{NO}_{x}$ that reached photochemical equilibrium during the daytime. When comparing modeled 
$\Delta^{17} \mathrm{O}$ (nitrate) with observations, we add error bars to model values in these locations (Beijing and Mt. Lulin, Taiwan) that reflect the range of possible $A$ values for nighttime nitrate formation, with the high end $\left(A_{\text {high }}\right)$ reflecting $24 \mathrm{~h}$ average $A$ values and the low end assuming that half of nitrate formation occurs from oxidation of $\mathrm{NO}_{x}$ that reached photochemical equilibrium during the daytime $\left(A_{\text {low }}=0.5 A+0.5 A_{\text {night }}\right.$, where $A_{\text {night }}=0.5$ ).

$\Delta{ }^{17} \mathrm{O}$ (nitrate) for total nitrate is calculated in the model according to

$\Delta^{17} \mathrm{O}($ nitrate $)=\sum_{\mathrm{R}=\mathrm{R} 1}^{\mathrm{R} 10} f_{\mathrm{R}} \Delta^{17} \mathrm{O}(\text { nitrate })_{\mathrm{R}}$,

where $f_{\mathrm{R}}$ represents the fractional importance of each nitrate production pathway (R1-R10 in Table 1) relative to total nitrate production, and $\Delta{ }^{17} \mathrm{O}$ (nitrate) $)_{\mathrm{R}}$ is the $\Delta^{17} \mathrm{O}$ (nitrate) value for each reaction as described in Table 1 . To calculate $\Delta{ }^{17} \mathrm{O}$ (nitrate), we assume that the mean $\Delta^{17} \mathrm{O}$ value of the ozone molecule $\left(\Delta^{17} \mathrm{O}\left(\mathrm{O}_{3}\right)\right)$ is equal to $26 \%$ o based on recent observations (Vicars et al., 2012; Ishino et al., 2017; Vicars and Savarino, 2014) and that it is the terminal oxygen atom that is transferred to the oxidation product during chemical reactions (Savarino et al., 2008; Berhanu et al., 2012). Thus, we assume that the $\Delta^{17} \mathrm{O}$ value of the oxygen atom transferred from $\mathrm{O}_{3}\left(\Delta^{17} \mathrm{O}\left(\mathrm{O}_{3}^{*}\right)\right)=1.5 \times \Delta^{17} \mathrm{O}\left(\mathrm{O}_{3}\right)$, as in previous work (e.g., Morin et al., 2011), where $\Delta^{17} \mathrm{O}\left(\mathrm{O}_{3}^{*}\right)$ represents the $\Delta^{17} \mathrm{O}$ value of the terminal oxygen atoms in ozone. Assuming that $\Delta^{17} \mathrm{O}\left(\mathrm{O}_{3}\right)=26 \%$ based on recent observations, this leads to $\Delta^{17} \mathrm{O}\left(\mathrm{O}_{3}^{*}\right)=39 \%$.

\section{Results and discussion}

Figure 1 shows the relative importance of the different oxidation pathways of $\mathrm{NO}$ to $\mathrm{NO}_{2}$ and nitrate formation below $1 \mathrm{~km}$ altitude in the model for the cloud chemistry simulation, with equivalent values for the standard simulation shown in parentheses. We focus on model results near the surface (below $1 \mathrm{~km}$ ) because these can be compared to observations; currently only surface observations of $\Delta^{17} \mathrm{O}$ (nitrate) are available. We note that two observation data sets - from Bermuda (Hastings et al., 2003) and Princeton, NJ (Kaiser et al., 2007) - are rainwater samples and thus may represent nitrate formed aloft. However, since cloud water peaks on average near $1 \mathrm{~km}$ altitude in the MERRA2 meteorology used to drive GEOS-Chem, our model sampling strategy should capture the majority of the influence of clouds on the chemistry of nitrate formation. The dominant oxidant of $\mathrm{NO}$ to $\mathrm{NO}_{2}$ is $\mathrm{O}_{3}(84 \%-85 \%)$. Much of the remaining oxidation occurs due to the reaction with peroxy radicals $\left(\mathrm{HO}_{2}\right.$ and $\left.\mathrm{RO}_{2}\right)$. Oxidation of $\mathrm{NO}$ to $\mathrm{NO}_{2}$ by $\mathrm{XO}$ is minor (1\%) and occurs over the oceans because the main source of tropospheric reactive halogens is from sea salt aerosol and sea water (Chen et al., 2017; Sherwen et al., 2016; Wang et al., 2019) (Fig. 2). In
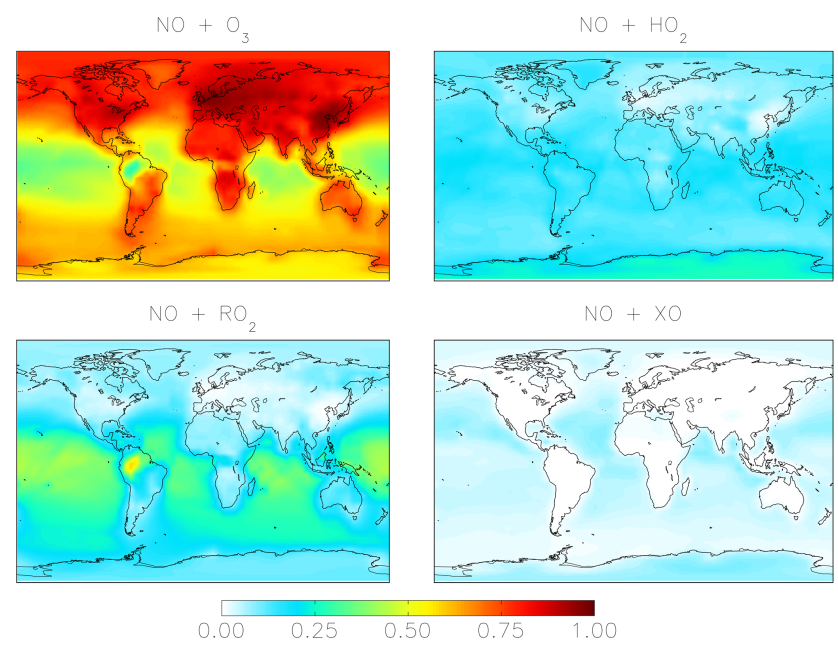

Figure 2. Annual-mean fraction of $\mathrm{NO}_{2}$ formation from the oxidation of $\mathrm{NO}$ in the troposphere below $1 \mathrm{~km}$ altitude in the cloud chemistry model.

the model, the global annual-mean lifetime of $\mathrm{NO}_{x}$ in the troposphere against oxidation to nitrate is about $1 \mathrm{~d}$; about $50 \%$ of this loss is from the reaction of $\mathrm{NO}_{2}+\mathrm{OH} . \mathrm{NO}_{x}$ loss from $\mathrm{N}_{2} \mathrm{O}_{5}$ becomes more important near the surface where aerosol surface area is relatively high. The global annualmean lifetime of nitrate in the troposphere against wet and dry deposition to the surface is about $3 \mathrm{~d}$.

For both the cloud chemistry and standard simulations, the two most important nitrate formation pathways are $\mathrm{NO}_{2}+\mathrm{OH}(41 \%-42 \%)$ and $\mathrm{N}_{2} \mathrm{O}_{5}$ hydrolysis $(28 \%-41 \%)$, the latter of which is dominant over the mid- to high northern continental latitudes during winter, where both $\mathrm{NO}_{x}$ emissions and aerosol abundances are relatively large (Figs. 1 and 3 ). The cloud chemistry simulation results in an equal importance of nitrate formation via $\mathrm{NO}_{2}+\mathrm{OH}$ and $\mathrm{N}_{2} \mathrm{O}_{5}$ hydrolysis (both $41 \%$ ) due to increases in the rate of $\mathrm{N}_{2} \mathrm{O}_{5}$ uptake in clouds and decreases in the importance of $\mathrm{NO}_{2}$ hydrolysis, which can compete with $\mathrm{N}_{2} \mathrm{O}_{5}$ formation at night. In the standard model, $\mathrm{NO}_{2}$ hydrolysis represents an important nitrate production mechanism $(12 \%)$, but it is negligible in the cloud chemistry simulation due to the reduction in the reaction probability (from $\gamma \mathrm{NO}_{2}=10^{-4}$ to $\gamma \mathrm{NO}_{2}=10^{-4}$ to $10^{-8}$ ) in the model, which is supported by laboratory studies (Burkholder et al., 2015; Crowley et al., 2010; Tan et al., 2016). The formation of $\mathrm{HNO}_{3}$ from the hydrolysis of $\mathrm{RONO}_{2}$ formed from both daytime $\left(\mathrm{NO}+\mathrm{RO}_{2}\right)$ and nighttime $\left(\mathrm{NO}_{3}+\mathrm{MTN} / \mathrm{ISOP}\right)$ reactions represents $6 \%$ of total global nitrate formation (Fig. 1) and is dominant over Amazonia (Fig. 3). $\mathrm{RONO}_{2}$ hydrolysis represents up to $20 \%$ of inorganic nitrate formation in the southeastern US (Fig. 3). This is similar to Fisher et al. (2016), who estimated that formation of $\mathrm{RONO}_{2}$ accounts for up to $20 \%$ of $\mathrm{NO}_{x}$ loss in this region during summer, with $\mathrm{RONO}_{2}$ hydrolysis representing $60 \%$ of $\mathrm{RONO}_{2}$ loss. Globally, the formation of in- 

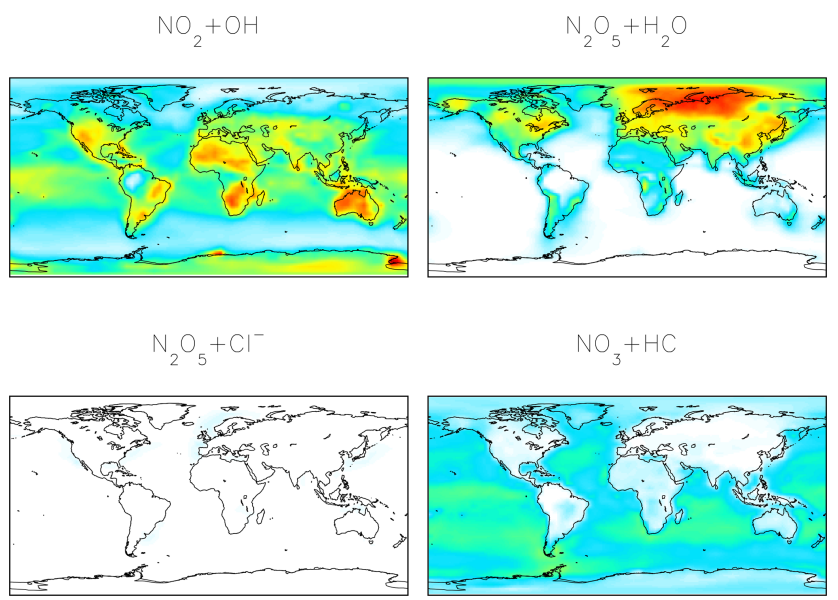

$\mathrm{XNO}+\mathrm{H}_{2} \mathrm{O}$
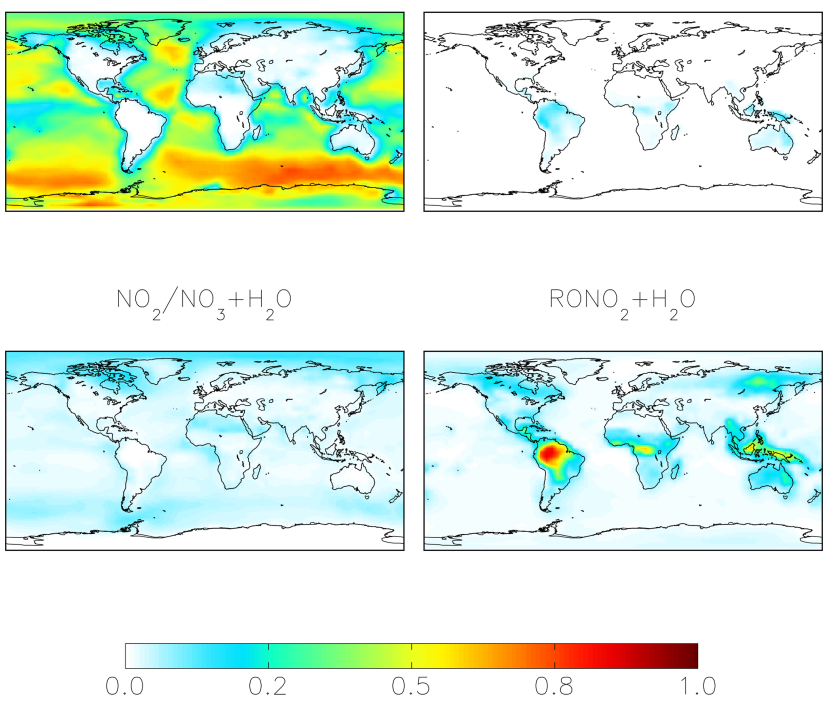

Figure 3. Annual-mean fraction of $\mathrm{HNO}_{3}$ formation from the oxidation of $\mathrm{NO}_{x}$ in the troposphere below $1 \mathrm{~km}$ altitude in the cloud chemistry model.

organic nitrate from the hydrolysis of $\mathrm{RONO}_{2}$ is dominated by $\mathrm{RONO}_{2}$ formation from the daytime reactions $(3 \%-6 \%)$, while the formation of $\mathrm{RONO}_{2}$ from nighttime reactions represents up to $3 \%$. The relative importance of nighttime and daytime $\mathrm{RONO}_{2}$ formation is expressed as a range because precursors to $\mathrm{RONO}_{2}$ that formed from monoterpenes can form from both daytime and nighttime reactions, and these precursors are not separately diagnosed in the model output. $\mathrm{HNO}_{3}$ formation from $\mathrm{NO}_{3}+\mathrm{HC}$ and the hydrolysis of $\mathrm{XNO}_{3}$ is small globally (5\%-6\%). Although $\mathrm{XNO}_{3}$ hydrolysis is the dominant nitrate formation pathway over the remote oceans (Fig. 3), its contribution to total global nitrate production is relatively small due to small local $\mathrm{NO}_{x}$ sources in these regions.

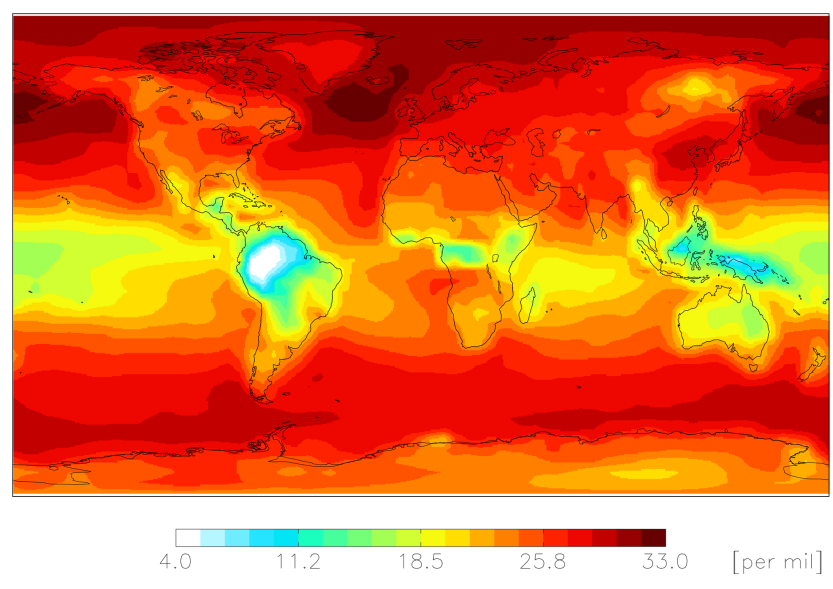

Figure 4. Modeled annual-mean $\Delta^{17} \mathrm{O}$ (nitrate) below $1 \mathrm{~km}$ altitude for the cloud chemistry model.

Figures 4-6 show modeled $\Delta^{17} \mathrm{O}$ (nitrate) for the cloud chemistry simulation (the standard simulation is shown in Figs. S2-S4). Figure 4 shows modeled annual-mean $\Delta{ }^{17} \mathrm{O}$ (nitrate) below $1 \mathrm{~km}$ altitude $\left(\Delta^{17} \mathrm{O}\left(\mathrm{NO}_{2}\right)\right.$ is shown in Fig. S5). The model predicts an annual-mean range of $\Delta{ }^{17} \mathrm{O}$ (nitrate) $=4 \%$ - $33 \%$ near the surface. The lowest values are over Amazonia due to the dominance of $\mathrm{RONO}_{2}$ hydrolysis, and the highest values are over the midlatitude oceans due to the dominance of $\mathrm{XNO}_{3}$ hydrolysis (Figs. 3 and 4).

Figure 5 compares the model with a global compilation of $\Delta^{17} \mathrm{O}$ (nitrate) observations from around the world. Observations included in Fig. 5 include locations where there is enough data to calculate monthly means (McCabe et al., 2006; Kunasek et al., 2008; Hastings et al., 2003; Kaiser et al., 2007; Michalski et al., 2003; Guha et al., 2017; Savarino et al., 2013, 2007; Ishino et al., 2017; Alexander et al., 2009; He et al., 2018b; Fibiger et al., 2013; Wang et al., 2014). Figure 6 compares the seasonality in modeled $\Delta^{17} \mathrm{O}$ (nitrate) to the observations where samples were collected over the course of approximately 1 year (McCabe et al., 2006; Kunasek et al., 2008; Kaiser et al., 2007; Michalski et al., 2003; Guha et al., 2017; Savarino et al., 2013, 2007; Ishino et al., 2017; Alexander et al., 2009). In contrast to Alexander et al. (2009), the model does not significantly underestimate the $\Delta^{17} \mathrm{O}$ (nitrate) observations when assuming a bulk ozone isotopic composition $\left(\Delta^{17} \mathrm{O}\left(\mathrm{O}_{3}\right)\right)$ on the order of $25 \%$ (see Fig. 2d in Alexander et al., 2009). The increase in modeled $\Delta^{17} \mathrm{O}$ (nitrate) is due to increased importance of $\mathrm{O}_{3}$ in $\mathrm{NO}_{x}$ cycling ( $85 \%$ below $1 \mathrm{~km}$ ) compared to Alexander et al. (2009) (80\% below $1 \mathrm{~km}$ altitude), as well as an increase in the number and fractional importance of nitrate formation pathways that yield relatively high values of $\Delta^{17} \mathrm{O}$ (nitrate) (red pathways in Fig. 1). Although XO species themselves are only a minor NO oxidation pathway (1\%), the addition of reactive halogen chemistry in the model has 
altered the relative abundance of $\mathrm{O}_{3}$ and $\mathrm{HO}_{x}$ (Sherwen et al., $2016)$ in such a way as to increase the modeled $\Delta^{17} \mathrm{O}\left(\mathrm{NO}_{x}\right)$. The Alexander et al. (2009) study used GEOS-Chem v801-01, which included tropospheric nitrate formation from the $\mathrm{NO}+\mathrm{OH}, \mathrm{N}_{2} \mathrm{O}_{5}+\mathrm{H}_{2} \mathrm{O}$, and $\mathrm{NO}_{3}+\mathrm{HC}$ pathways only. An increased importance of $\mathrm{N}_{2} \mathrm{O}_{5}$ hydrolysis (R4) and additional nitrate formation pathways that yield relatively high values of $\Delta^{17} \mathrm{O}$ (nitrate) (R5, R6, R8, and R10) in the present study also explain the increase in modeled $\Delta^{17} \mathrm{O}$ (nitrate) relative to Alexander et al. (2009). An increase in the average $A$ value from 0.80 to 0.85 would tend to increase the calculated $\Delta{ }^{17} \mathrm{O}$ (nitrate) on the order of $2 \% 0\left(0.05 \times \Delta^{17} \mathrm{O}\left(\mathrm{O}_{3}^{*}\right)\right)$, suggesting that the increase in the relative importance of the terminal reactions R4, R5, R6, R8, and R10 explains the majority of the difference between the results presented here compared to Alexander et al. (2009). Assuming a value of $35 \%$ o for bulk $\Delta{ }^{17} \mathrm{O}\left(\mathrm{O}_{3}\right)$ in the model that did not include reactive halogen chemistry or heterogeneous reactions in cloud water produced good agreement between modeled and observed $\Delta^{17} \mathrm{O}$ (nitrate) in Alexander et al. (2009); however, in the current version of the model this bulk isotopic assumption leads to a model overestimate at nearly all locations (Fig. S6). The cloud chemistry model shows somewhat better agreement with the observations $\left(R^{2}=0.51\right.$ in Fig. 5) compared to the standard model $\left(R^{2}=0.48\right.$ in Fig. S3). Improved agreement with the observations occurs in the mid- to high latitudes (Figs. 6 and S4) and is due to addition of $\mathrm{N}_{2} \mathrm{O}_{5}$ hydrolysis in clouds (Figs. 3 and S6).

The mean $\Delta^{17} \mathrm{O}$ (nitrate) value of the observations (27.7 \pm $5.0 \%$ ) shown in Fig. 5 is not significantly different from the modeled values at the location of the observations $\left(28.6 \pm 4.5 \%\right.$ ) ; however, the range of $\Delta^{17} \mathrm{O}$ (nitrate) values of the observations $(10.9 \%$ - $40.6 \%$ ) $)$ is larger than in the model $(19.6 \%$ - $37.6 \%$ ). As previously noted in Savarino et al. (2007), the maximum observed $\Delta^{17} \mathrm{O}$ (nitrate) value $(40.6 \%$ ) is not possible given our isotope assumption for the terminal oxygen atom of ozone $\left(\Delta^{17} \mathrm{O}\left(\mathrm{O}_{3}^{*}\right)=39 \%\right.$ ); however, it is theoretically possible given the approximately $2 \%$ uncertainty in observed $\Delta^{17} \mathrm{O}\left(\mathrm{O}_{3}^{*}\right)$. A value of $\Delta{ }^{17} \mathrm{O}$ (nitrate $)=41 \%$ is possible if $\Delta^{17} \mathrm{O}\left(\mathrm{O}_{3}^{*}\right)=41 \%$ and all oxygen atoms of nitrate originate from ozone $(A=1$ and all nitrate forms from R2 and/or R5). Although this may be possible for nitrate formed locally in the Antarctic winter due to little to no sunlight, lack of local $\mathrm{NO}_{x}$ sources during Antarctic winter makes it unlikely that all nitrate observed in Antarctica forms locally. Long-range transport from lower latitudes and/or the stratosphere likely contributes to nitrate observed in Antarctica during winter (Lee et al., 2014). Observed $\Delta{ }^{17} \mathrm{O}$ (nitrate) $>39 \%$ (in Antarctica) has been suggested to be due to transport of nitrate from the stratosphere (Savarino et al., 2007), as stratospheric $\mathrm{O}_{3}$ is expected to have a higher $\Delta{ }^{17} \mathrm{O}\left(\mathrm{O}_{3}\right)$ value than ozone produced in the troposphere (Krankowsky et al., 2000; Mauersberger et al., 2001; Lyons, 2001). Indeed, the model underestimates the observations at Dumont d'Urville (DDU) and the South Pole (both in Antarctica) during winter and spring (Fig. 6), where and when the stratospheric contribution is expected to be most important (Savarino et al., 2007). The model underestimate in Antarctica may also be due to model underestimates of the BrO column (Chen et al., 2017) and ozone abundance (Sherwen et al., 2016) in the southern high latitudes. The largest model overestimates occur at Mt. Lulin, Taiwan (Figs. 5 and 6). Based on nitrogen isotope observations $\left(\delta^{15} \mathrm{~N}\right)$, nitrate at Mt. Lulin is thought to be influenced by anthropogenic nitrate emitted in polluted areas of mainland China and transported to Mt. Lulin rather than local nitrate production (Guha et al., 2017). However, observations of $\Delta^{17} \mathrm{O}$ (nitrate) in autumn and winter in Beijing suggest much higher values $(30.6 \pm 1.8 \%$ ) than was measured at Mt. Lulin (15\%o-30\%o in winter). A potential reason for the model overestimate of the observed values at Mt. Lulin could be qualitatively explained by transport of nitrate formed in the free troposphere to this high-altitude location, where the high- $\Delta^{17} \mathrm{O}$ (nitrate)-producing pathways (R4-R8) should be negligible due to minimal aerosol surface area for heterogeneous chemistry. Low $\Delta^{17} \mathrm{O}$ (nitrate) values from nitrate formed at higher altitudes and transported to Mt. Lulin would not be accounted for in the model since the isotopes are not transported. The model compares better to the midlatitude locations close to pollution sources (La Jolla and Princeton), although the model overestimates wintertime $\Delta^{17} \mathrm{O}$ (nitrate) in Princeton, NJ, USA, by up to $6 \%$ and underestimates winter time $\Delta{ }^{17} \mathrm{O}$ (nitrate) in La Jolla, CA, USA, by up to $4 \%$ 。 The model overestimate at Princeton during winter could be due to the fact that these are precipitation samples and not ambient aerosol samples, and thus may reflect nitrate formed at altitudes higher than we are sampling in the model. The underestimate at La Jolla, CA, could be due to underestimates in reactive chlorine chemistry in the model, which would tend to increase $\Delta^{17} \mathrm{O}$ (nitrate) by increasing nitrate formation by the hydrolysis of halogen nitrates (R6) in this coastal location. The model underestimates the $\Delta{ }^{17} \mathrm{O}$ (nitrate) observations at Cabo Verde in late summer/early autumn by up to $6 \%$ (Savarino et al., 2013). Comparison with results from the steady-state model employed in Savarino et al. (2013) suggests that the low bias could be due to an underestimate of nitrate formation via $\mathrm{NO}_{3}+\mathrm{DMS}$ (R2). The steady-state model in Savarino et al. (2013) agreed with observations when R2 represented about one-third of total nitrate formation. The model results presented here have R2 representing about $15 \%$ of total nitrate formation in this season. An underestimate of the relative importance of R2 could result from a model underestimate of atmospheric DMS abundances. 


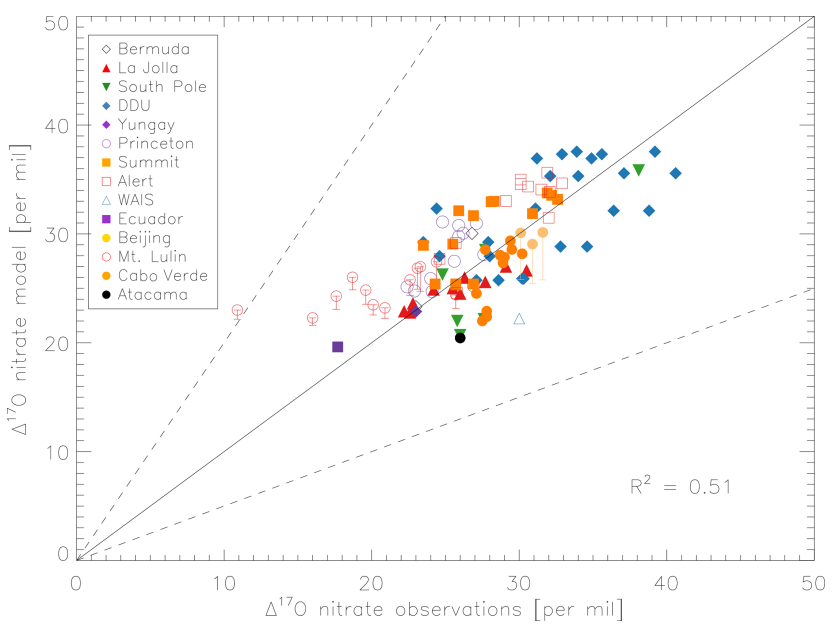

Figure 5. Comparison of monthly-mean modeled (cloud chemistry) and observed $\Delta^{17} \mathrm{O}$ (nitrate) at locations where there are enough observations to calculate a monthly mean. References for the observations are in the text. The error bars represent different assumptions for calculated modeled $A$ values for nighttime reactions as described in the text. Error bars for Beijing and Mt. Lulin reflect the range of possible modeled $A$ values for nighttime reactions as described in the text. The $y=x$ (solid line) and $y=2 x$ and $y=0.5 x$ (dashed) are shown.

\section{Model uncertainties}

The uncertainty in the two most important nitrate formation pathways, $\mathrm{NO}_{2}+\mathrm{OH}$ and $\mathrm{N}_{2} \mathrm{O}_{5}$ hydrolysis, and their impacts on $\mathrm{NO}_{x}$ and oxidant budgets have been examined and discussed elsewhere (Macintyre and Evans, 2010; Newsome and Evans, 2017; Holmes et al., 2019). The impacts of the formation and hydrolysis of halogen nitrates on global $\mathrm{NO}_{x}$ and oxidant budgets have also been previously examined (Sherwen et al., 2016). Here we focus on three additional processes using a set of model sensitivity studies. First, we examine the importance of the third most important nitrate production pathway on the global scale as predicted by the standard model, $\mathrm{NO}_{2}$ aerosol uptake and hydrolysis, and its implications for the global $\mathrm{NO}_{x}$, nitrate, and oxidant budgets. Second, we examine the role of changing anthropogenic $\mathrm{NO}_{\mathrm{x}}$ emissions over a 15-year period (2000 to 2015) on the relative importance of the formation of inorganic nitrate from the hydrolysis of organic nitrates. Finally, we examine the role of aerosol nitrate photolysis on the relative importance of different nitrate formation pathways. The impact of aerosol nitrate photolysis on $\mathrm{NO}_{x}$ and oxidant budgets has been examined in detail elsewhere (Kasibhatla et al., 2018).

\subsection{Heterogeneous uptake and hydrolysis of $\mathrm{NO}_{2}$}

Heterogeneous uptake of $\mathrm{NO}_{2}$ to form $\mathrm{HNO}_{3}$ and $\mathrm{HONO}$ is the third most important nitrate formation pathway in the standard model on the global scale (Fig. 1). The reaction

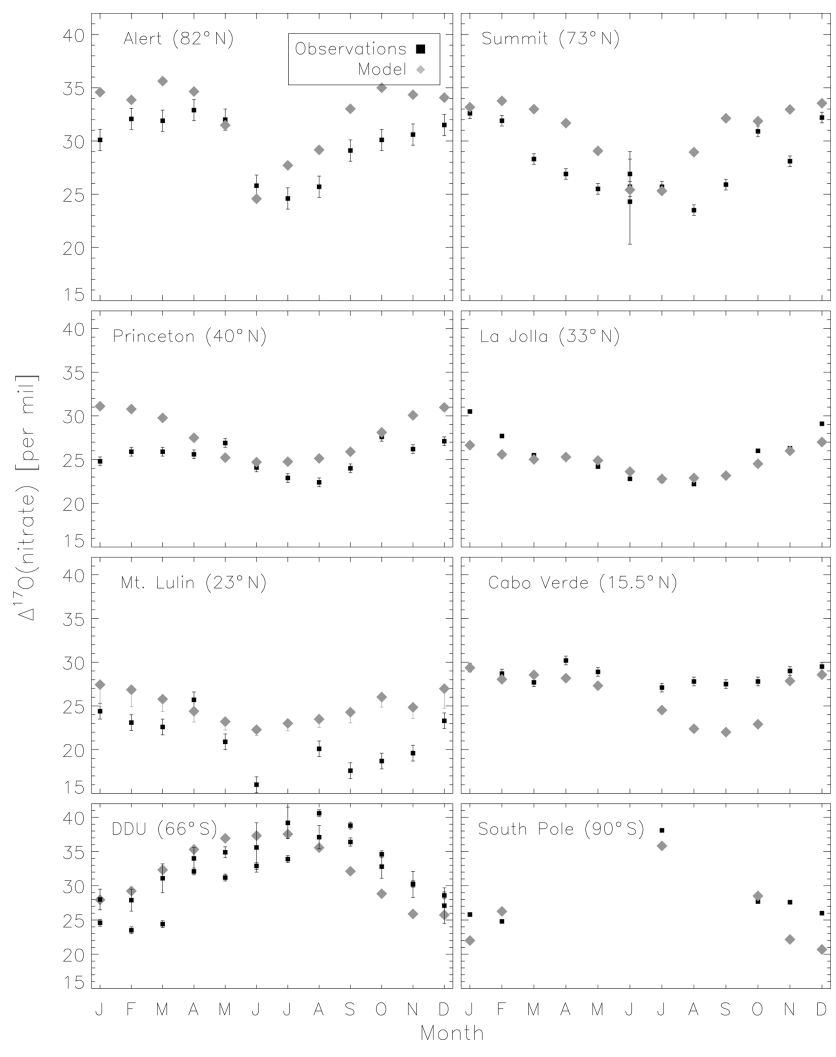

Figure 6. Comparison of monthly-mean modeled (cloud chemistry) and observed $\Delta^{17} \mathrm{O}$ (nitrate). Error bars for model results from Mt. Lulin reflect the range of possible modeled $A$ values for nighttime reactions as described in the text. Error bars for the observations reflect the analytical uncertainty in the measurements, except for two data points in June for Summit which reflect the standard deviation of $\Delta^{17} \mathrm{O}$ (nitrate) from multiple measurements during that month.

probability $\left(\gamma \mathrm{NO}_{2}\right)$ measured in laboratory studies ranges between $10^{-8}$ and $10^{-4}$ depending on aerosol chemical composition (Lee and Tang, 1988; Crowley et al., 2010; Gutzwiller et al., 2002; Yabushita et al., 2009; Abbatt and Waschewsky, 1998; Burkholder et al., 2015; Bröske et al., 2003; Li et al., 2018a; $\mathrm{Xu}$ et al., 2018). A value of $\gamma \mathrm{NO}_{2}=10^{-4}$ is used in the standard model, which is at the high end of the reported range. A molar yield of 0.5 for both $\mathrm{HNO}_{3}$ and $\mathrm{HONO}$ formation is assumed in the model based on laboratory studies and hypothesized reaction mechanisms (Finlayson-Pitts et al., 2003; Jenkin et al., 1988; Ramazan et al., 2004; Yabushita et al., 2009). However, both the reaction rate and mechanism of this reaction and its dependence on chemical composition and $\mathrm{pH}$ are still not well understood (Spataro and Ianniello, 2014).

The cloud chemistry simulation uses a reaction probability formulation for aerosol uptake of $\mathrm{NO}_{2}\left(\gamma_{\mathrm{NO}_{2}}\right)$ that depends on aerosol chemical composition, ranging from $\left(\gamma / \mathrm{NO}_{2}\right)=10^{-8}$ for dust to $\left(\gamma \mathrm{NO}_{2}\right)=10^{-4}$ for black carbon based on recent laboratory studies (Holmes et al., 2019). 

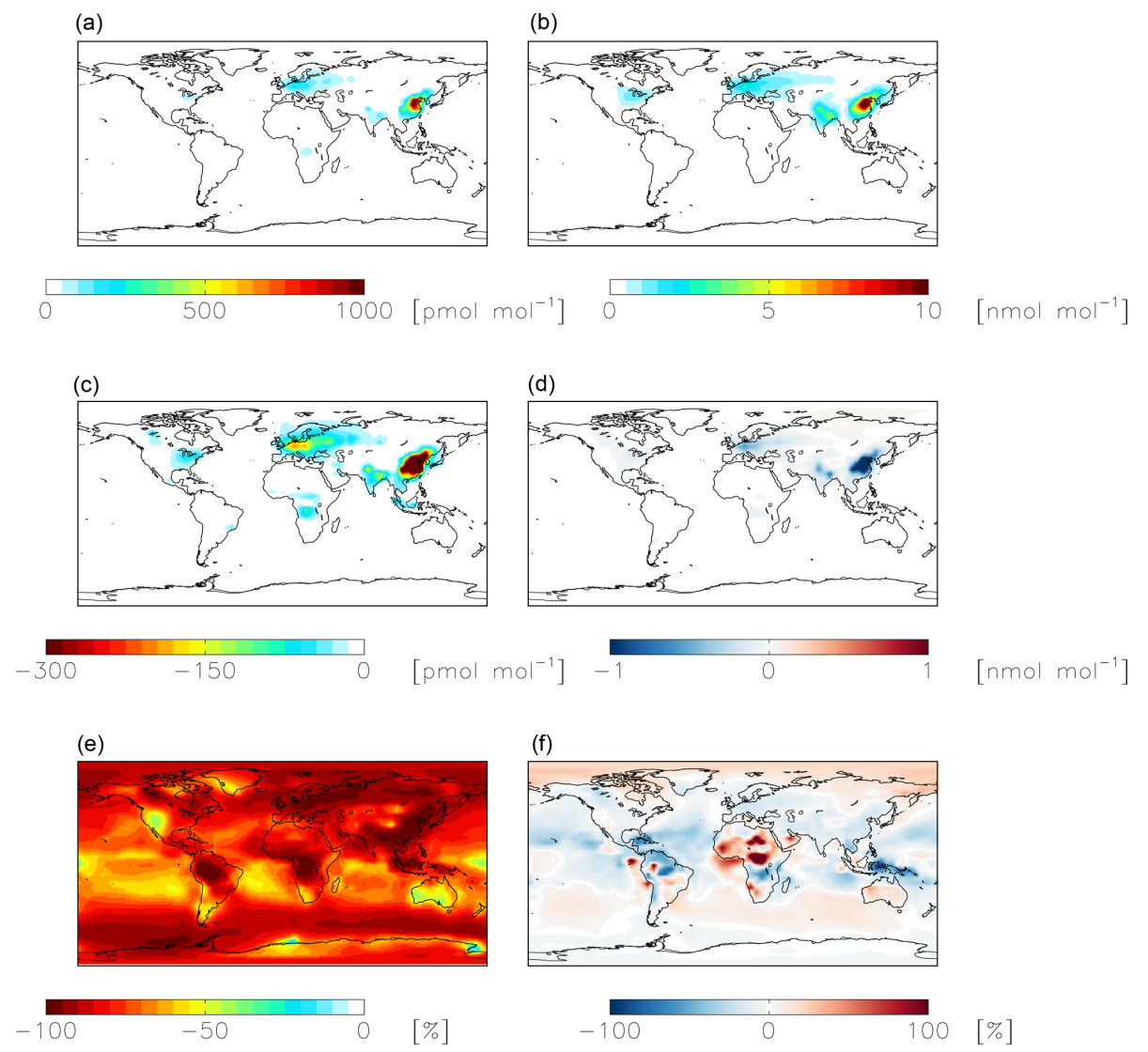

Figure 7. Modeled annual-mean $\mathrm{HONO}(\mathbf{a}, \mathbf{c}, \mathbf{e})$ and fine-mode nitrate $(\mathbf{b}, \mathbf{d}, \mathbf{f})$ concentrations below $1 \mathrm{~km}$ altitude in the standard simulation (a, b) with $\gamma \mathrm{NO}_{2}=10^{-4}$ for $\mathrm{NO}_{2}$ hydrolysis. Absolute $(\mathbf{c}, \mathbf{d})$ and relative $(\mathbf{e}, \mathbf{f})$ change in concentrations below $1 \mathrm{~km}$ altitude between the standard model and the model simulation with $\gamma_{\mathrm{NO}_{2}}=10^{-7}$. Negative numbers represent a decrease relative to the standard simulation.

The updated $\mathrm{NO}_{2}$ reaction probability results in a negligible $(<1 \%)$ importance of this reaction for nitrate formation, compared to a $12 \%$ contribution in the standard model. The cloud chemistry simulation significantly increases the fractional importance of $\mathrm{N}_{2} \mathrm{O}_{5}$ hydrolysis (from $28 \%$ to $41 \%$, globally below $1 \mathrm{~km}$ altitude) compared to the standard simulation, in part due to decreased competition from $\mathrm{NO}_{2}$ hydrolysis and in part due to increased $\mathrm{N}_{2} \mathrm{O}_{5}$ hydrolysis in clouds. To evaluate the relative importance of competition from $\mathrm{NO}_{2}$ hydrolysis and the addition of $\mathrm{N}_{2} \mathrm{O}_{5}$ hydrolysis in clouds, we perform a model sensitivity study that is the same as the standard simulation but decreases the reaction probability of $\mathrm{NO}_{2}$ hydrolysis on aerosol $\left(\mathrm{N}_{2} \mathrm{O}_{5}=10^{-7}\right)$, without adding $\mathrm{N}_{2} \mathrm{O}_{5}$ hydrolysis in clouds. Similar to the cloud chemistry simulation, using $\mathrm{N}_{2} \mathrm{O}_{5}=10^{-7}$ renders $\mathrm{NO}_{2}$ hydrolysis a negligible nitrate formation pathway and increases the relative importance of $\mathrm{N}_{2} \mathrm{O}_{5}$ hydrolysis from $28 \%$ to $37 \%$. This suggests that reduced competition from $\mathrm{NO}_{2}$ hydrolysis is the main reason for the increased importance of $\mathrm{N}_{2} \mathrm{O}_{5}$ hydrolysis in the cloud chemistry simulation, though the addition of heterogeneous reactions on clouds also plays a role.
$\mathrm{NO}_{2}$ hydrolysis represents a significant source of HONO in the standard model simulation; the reduced $\mathrm{NO}_{2}$ reaction probability from $\mathrm{N}_{2} \mathrm{O}_{5}=10^{-4}$ to $\mathrm{N}_{2} \mathrm{O}_{5}=10^{-7}$ results in a reduction of HONO below $1 \mathrm{~km}$ altitude by up to $100 \%$ over the continents, with relatively small (up to $1 \mathrm{ppb}$ ) changes in nitrate concentrations (Fig. 7). The reduction in the rate of heterogeneous $\mathrm{NO}_{2}$ uptake leads to reductions in $\mathrm{OH}$ where this reaction was most important in the model (over China and Europe) due to reductions in HONO but leads to increases in $\mathrm{OH}$ elsewhere due to increases in ozone (by up to a few ppb) resulting from small increases in the $\mathrm{NO}_{x}$ lifetime due to a reduction in the $\mathrm{NO}_{x}$ sink (Fig. 8). Similar changes in HONO are seen when comparing the standard and cloud chemistry simulation (not shown). Increased importance of $\mathrm{N}_{2} \mathrm{O}_{5}$ hydrolysis in both the cloud chemistry simulation and the simulation without cloud chemistry but with a reduced reaction probability for $\mathrm{NO}_{2}$ hydrolysis increases modeled annual-mean $\Delta^{17} \mathrm{O}$ (nitrate) by up to $3 \%$ in China, where this reaction is most important. This improves model agreement with monthly-mean observations of $\Delta^{17} \mathrm{O}$ (nitrate) in Beijing (He et al., 2018a) (Figs. 5 and S3). 
(a)

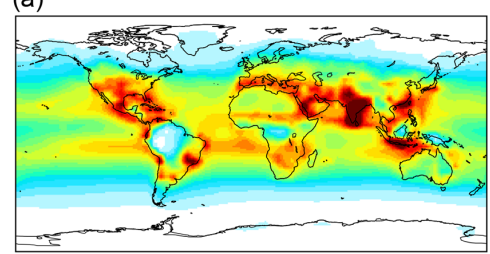

(b)
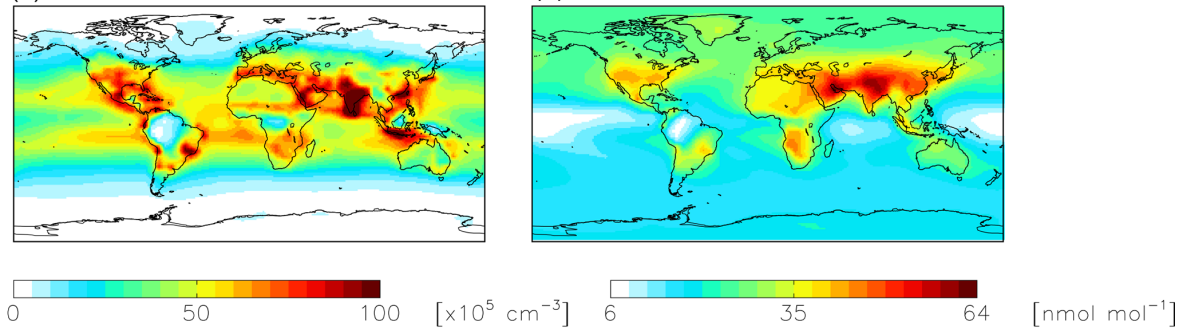

(c)

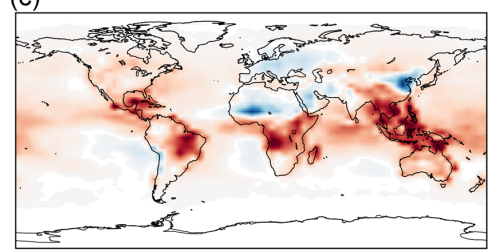

(d)

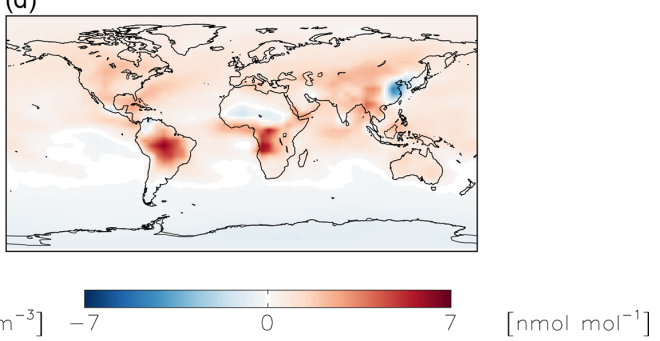

(e)
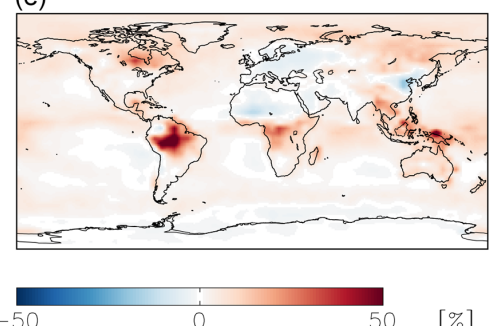

$[\%]$
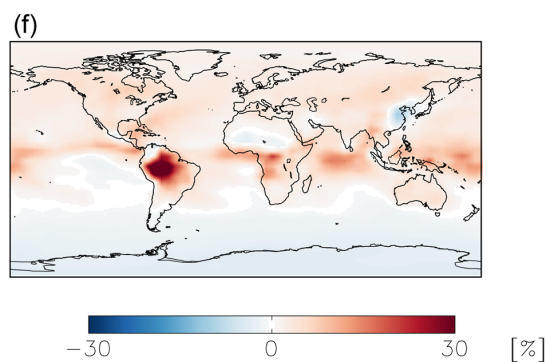

Figure 8. Same as Fig. 7 except for $\mathrm{OH}(\mathbf{a}, \mathbf{c}, \mathbf{e})$ and ozone $(\mathbf{b}, \mathbf{d}, \mathbf{f})$.

(a)

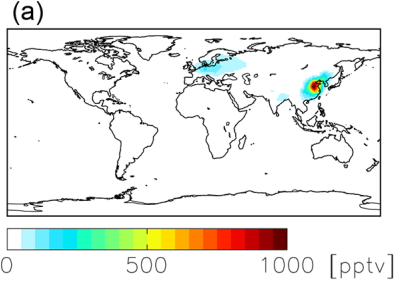

(d)

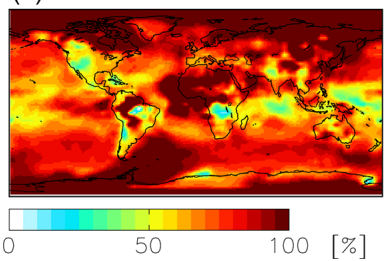

(b)

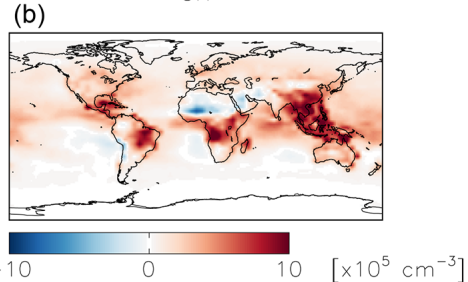

(e)

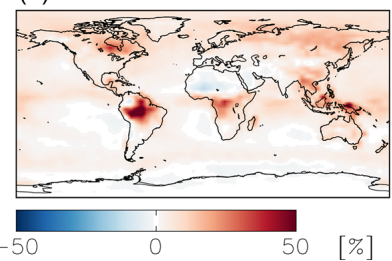

(c)
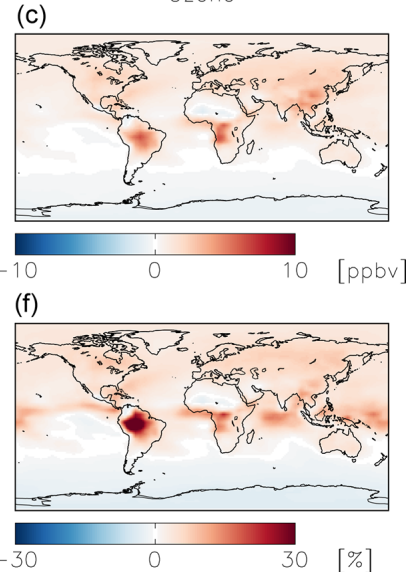

Figure 9. Absolute $(\mathbf{a}, \mathbf{b}, \mathbf{c})$ and relative $(\mathbf{d}, \mathbf{e}, \mathbf{f})$ change in HONO (a, d), OH (b, e), and ozone (c, f) concentrations below $1 \mathrm{~km}$ altitude between the standard model and the model simulation with an acidity-dependent yield from $\mathrm{NO}_{2}$ hydrolysis. Positive numbers represent an increase relative to the standard simulation. 


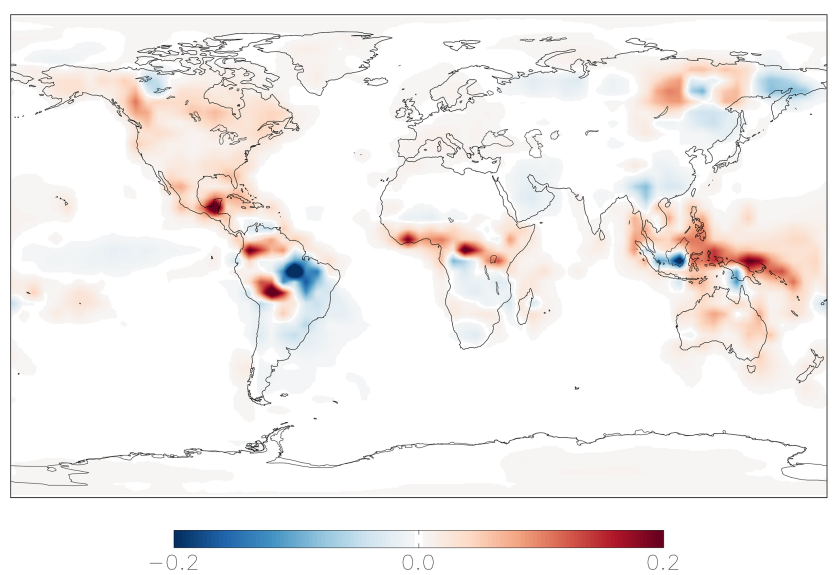

Figure 10. Modeled annual-mean difference in the fractional production rate of $\mathrm{HNO}_{3}$ from the hydrolysis of organic nitrate below $1 \mathrm{~km}$ attitude in the year 2015 relative to 2000 (2015-2000).

The product yields of $\mathrm{NO}_{2}$ hydrolysis are also uncertain. Jenkin et al. (1988) proposed the formation of a water complex, $\mathrm{NO}_{2} \cdot \mathrm{H}_{2} \mathrm{O}$, leading to the production of $\mathrm{HONO}$ and $\mathrm{HNO}_{3}$. Finlayson-Pitts et al. (2003) and Ramazan et al. (2004) proposed the formation of the dimer $\mathrm{N}_{2} \mathrm{O}_{4}$ on the surface, followed by isomerization to form $\mathrm{NO}^{+} \mathrm{NO}_{3}^{-}$. Reaction of $\mathrm{NO}^{+} \mathrm{NO}_{3}^{-}$with $\mathrm{H}_{2} \mathrm{O}$ results in the formation of $\mathrm{HONO}$ and $\mathrm{HNO}_{3}$. Laboratory experiments by Yabushita et al. (2009) suggested that dissolved anions catalyzed the dissolution of $\mathrm{NO}_{2}$ to form a radical intermediate $\mathrm{XNO}_{2}^{-}$(where $\mathrm{X}=\mathrm{Cl}, \mathrm{Br}$, or I) at the surface followed by reaction with $\mathrm{NO}_{2}(\mathrm{~g})$ to form $\mathrm{HONO}$ and $\mathrm{NO}_{3}^{-}$. These experiments described above were performed at $\mathrm{NO}_{2}$ concentrations much higher than exist in the atmosphere (10-100 ppm) (Yabushita et al., 2009; Finlayson-Pitts et al., 2003; Ramazan et al., 2004). A laboratory study utilizing isotopically labeled water to investigate the reaction mechanism suggested that the formation of HONO resulted from the reaction between adsorbed $\mathrm{NO}_{2}$ and $\mathrm{H}^{+}$, while the formation of $\mathrm{HNO}_{3}$ resulted from the reaction between adsorbed $\mathrm{NO}_{2}$ and $\mathrm{OH}^{-}$, and did not involve the $\mathrm{N}_{2} \mathrm{O}_{4}$ intermediate (Gustafsson et al., 2009). Results from Gustafsson et al. (2009) suggest an aciditydependent yield of $\mathrm{HONO}$ and $\mathrm{HNO}_{3}$, favoring $\mathrm{HONO}$ at low $\mathrm{pH}$ values. A recent study in the northeastern US during winter found that modeled nitrate abundance was overestimated using a molar yield of 0.5 for $\mathrm{HONO}$ and $\mathrm{HNO}_{3}$, and the model better matched the observations of $\mathrm{NO}_{2}$ and nitrate when assuming a molar yield of 1.0 for HONO (Jaeglé et al., 2018). Particles were acidic $(\mathrm{pH}<2)$ during this measurement campaign (Guo et al., 2017; Shah et al., 2018), which may favor HONO production over $\mathrm{HNO}_{3}$.

We examine the potential importance of this aciditydependent yield by implementing a $\mathrm{pH}$-dependent product yield in two separate sensitivity simulations, first using an $\mathrm{NO}_{2}$ aerosol uptake reaction probability of $\gamma=10^{-4}$ as in the standard simulation and second with $\gamma \mathrm{NO}_{2}=10^{-7}$. The acidity-dependent yield for $\mathrm{HONO}$ and $\mathrm{HNO}_{3}$ formation is based on the laboratory study by Gustafsson et al. (2009). We use aerosol pH calculated from ISORROPIA II (Fountoukis and Nenes, 2007) to calculate the concentration of $\mathrm{H}^{+}$and $\mathrm{OH}^{-}$in aerosol water. The yield of HONO $\left(\Upsilon_{\mathrm{HONO}}\right)$ from heterogeneous uptake of $\mathrm{NO}_{2}$ on aerosol surfaces is calculated according to Eq. (3):

$\Upsilon_{\mathrm{HONO}}=\frac{\left[\mathrm{H}^{+}\right]}{\left[\mathrm{H}^{+}\right]+\left[\mathrm{OH}^{-}\right]}$,

where $\left[\mathrm{H}^{+}\right]$and $\left[\mathrm{OH}^{-}\right]$are in units of $\mathrm{M}$. The yield of $\mathrm{HNO}_{3}$ from this reaction is equal to $\left(1-\Upsilon_{\text {HONO }}\right)$. Eq. (3) yields values of $\Upsilon_{\text {HONO }}$ near unity for aerosol $\mathrm{pH}$ values less than 6 , decreasing rapidly to zero between $\mathrm{pH}$ values of 6 and 8 (Fig. S8). Calculated aerosol $\mathrm{pH}$ values are typically $<6$ in the model except in remote regions far from $\mathrm{NO}_{x}$ sources (Fig. S9), favoring the product HONO.

The acidity-dependent yield implemented in the standard simulation with $\gamma \mathrm{NO}_{2}=10^{-4}$ increases $\mathrm{HONO}$ concentrations by up to $1 \mathrm{ppbv}$ in China, where this reaction is most important (Fig. 9). Fractional increases in HONO exceed $100 \%$ in remote locations (Fig. 9). Increased HONO leads to increases in $\mathrm{OH}$ on the order of $10 \%-20 \%$ in most locations below $1 \mathrm{~km}$ altitude, while ozone concentrations increase in most locations by up to several ppbv (Fig. 9). The exception is the southern high latitudes, likely due to decreased formation and thus transport of nitrate to remote locations. The impact on $\mathrm{NO}_{x}$ and nitrate budgets is relatively minor. The global annual-mean $\mathrm{NO}_{x}$ burden near the surface (below $1 \mathrm{~km})$ increases slightly $(+2 \%)$ as a result of the decreased rate of conversion of $\mathrm{NO}_{2}$ to nitrate; the change to the global tropospheric burden is negligible. Annual-mean surface nitrate concentrations show small decreases up to $1 \mathrm{ppbv}$ in China, where this reaction is most important in the model; impacts on nitrate concentrations over a shorter time period may be more significant (Jaeglé et al., 2018). The fraction of $\mathrm{HNO}_{3}$ formed from $\mathrm{NO}_{2}+\mathrm{OH}(49 \%)$ increases due to increases in $\mathrm{OH}$ from the HONO source. The fraction of $\mathrm{HNO}_{3}$ formation from the uptake and hydrolysis of $\mathrm{N}_{2} \mathrm{O}_{5}$ also increases (from $28 \%$ to $32 \%$ ) due to reductions in the nighttime source of nitrate from $\mathrm{NO}_{2}$ hydrolysis. The calculated mean $\Delta^{17} \mathrm{O}$ (nitrate) at the location of the observations shown in Fig. $5(27.9 \pm 5.0 \%$ o $)$ is not significantly impacted due to compensating effects from changes in both high- and low-producing $\Delta^{17} \mathrm{O}$ (nitrate) values. Modeled monthly-mean $\Delta^{17} \mathrm{O}$ (nitrate) in China, where $\mathrm{NO}_{2}$ hydrolysis is most important, decreases by $0.9 \% 0-1.9 \% o$ and is biased low by $1.8 \%-3.4 \%$.

Using a combination of both the low reaction probability $\left(\gamma=10^{-7}\right)$ and the acidity-dependent yield gives similar results to using $\gamma=10^{-7}$ and assuming a molar yield of 0.5 for $\mathrm{HONO}$ and $\mathrm{HNO}_{3}$ (not shown). In other words, including a $\mathrm{pH}$-dependent product yield rather than a yield of 0.5 
for $\mathrm{HONO}$ and nitrate results in negligible differences for oxidants, $\mathrm{NO}_{x}$ and nitrate abundances when the reaction probability $\left(\gamma_{\mathrm{NO}_{2}}\right)$ is low.

\subsection{Hydrolysis of organic nitrates $\left(\mathrm{RONO}_{2}\right)$}

Anthropogenic $\mathrm{NO}_{x}$ emissions have been increasing in China and decreasing in the US and Europe (Richter et al., 2005; Hoesly et al., 2018), with implications for the relative importance of inorganic and organic nitrate formation as a sink for $\mathrm{NO}_{x}$ (Zare et al., 2018). To examine the impacts of recent changes in anthropogenic $\mathrm{NO}_{x}$ emissions for nitrate formation pathways, we run the standard model using the year 2000 emissions and meteorology after a 1year model spin-up and compare the results to the standard model simulation run in the year 2015. This time period encompasses significant changes in anthropogenic $\mathrm{NO}_{x}$ emissions in the US, Europe, and China and encompasses most of the time period of the observations shown in Figs. 5 and 6. Total global anthropogenic emissions of $\mathrm{NO}_{x}$ are slightly lower in the year 2000 simulation $\left(30 \mathrm{Tg} \mathrm{N} \mathrm{yr}^{-1}\right)$ compared to the year 2015 simulation $\left(31 \mathrm{Tg} \mathrm{N} \mathrm{yr}^{-1}\right)$ due to decreases in North America and Europe, counteracted by increases in Asia (Fig. S10). This leads to increases of less than $10 \%$ in the annual-mean, fractional importance of the source of nitrate from the hydrolysis of organic nitrates in the US and corresponding decreases of less than $10 \%$ over China (Fig. 10). Relatively small changes $(<10 \%)$ in nitrate formation pathways yield small changes $(<2 \%$ ) in modeled annual-mean $\Delta^{17} \mathrm{O}$ (nitrate) between the year 2000 and 2015; differences in $\Delta^{17} \mathrm{O}$ (nitrate) over shorter time periods may be larger. Changes in the formation of nitrate from the hydrolysis of $\mathrm{RONO}_{2}$ remain unchanged globally, as increases in the US and Europe and decreases in China counteract one another.

\subsection{Photolysis of aerosol nitrate}

Observations have demonstrated that aerosol nitrate can be photolyzed at rates much faster than $\mathrm{HNO}_{3}$ (g) (Reed et al., 2017; Ye et al., 2016); however, the magnitude of the photolytic rate constant is uncertain. We examine the implications of this process for global nitrate formation pathways by implementing the photolysis of aerosol nitrate as described in Kasibhatla et al. (2018) into the standard model simulation, scaling the photolytic rate constant for both fine- and coarsemode aerosol nitrate to a factor of 25 times higher than that for $\mathrm{HNO}_{3}$ (g) (Kasibhatla et al., 2018; Romer et al., 2018), with a molar yield of 0.67 for $\mathrm{HONO}$ and 0.33 for $\mathrm{NO}_{x}$ production. The global annual-mean $\mathrm{NO}_{x}$ burden near the surface (below $1 \mathrm{~km}$ ) increases slightly $(+2 \%)$ as a result of the photolytic recycling of nitrate to $\mathrm{NO}_{x}$, similar to Kasibhatla et al. (2018). Aerosol nitrate photolysis results in only small impacts on the relative importance of nitrate formation pathways $(<2 \%)$, likely due to simultaneous increases in $\mathrm{O}_{3}$ and $\mathrm{OH}$ (Kasibhatla et al., 2018), which in turn yields small impacts on calculated $\Delta^{17} \mathrm{O}$ (nitrate) at the location of the observations shown in Fig. 5 (27.9 $\pm 5.0 \%$ o). Nitrate photolysis itself has minimal impact on $\Delta^{17} \mathrm{O}$ (nitrate) because it is a mass-dependent process (McCabe et al., 2005).

\section{Conclusions}

Observations of $\Delta^{17} \mathrm{O}$ (nitrate) can be used to help quantify the relative importance of different nitrate formation pathways. Interpretation of $\Delta^{17} \mathrm{O}$ (nitrate) requires knowledge of $\Delta^{17} \mathrm{O}\left(\mathrm{O}_{3}\right)$. Previous modeling studies showed good agreement between observed and modeled $\Delta^{17} \mathrm{O}$ (nitrate) when assuming a bulk oxygen isotopic composition of ozone $\left(\Delta^{17} \mathrm{O}\left(\mathrm{O}_{3}\right)\right)$ of $35 \%$ obased on laboratory and modeling studies (Morton et al., 1990; Thiemens, 1990; Lyons, 2001). However, recent and spatially widespread observations of $\Delta{ }^{17} \mathrm{O}\left(\mathrm{O}_{3}\right)$ have consistently shown $\Delta{ }^{17} \mathrm{O}\left(\mathrm{O}_{3}\right)=26 \pm 1 \%$, suggesting that models are underestimating the role of ozone relative to $\mathrm{HO}_{x}$ in $\mathrm{NO}_{x}$ chemistry. We utilize a global compilation of observations of $\Delta^{17} \mathrm{O}$ (nitrate) to assess the representation of nitrate formation in a global chemical transport model (GEOS-Chem), assuming that the bulk oxygen isotopic composition of ozone $\left(\Delta^{17} \mathrm{O}\left(\mathrm{O}_{3}\right)=26 \%\right.$. The modeled $\Delta^{17} \mathrm{O}$ (nitrate) is roughly consistent with observations, with a mean modeled and observed $\Delta^{17} \mathrm{O}$ (nitrate) of $(28.6 \pm 4.5 \% o)$ and $(27.6 \pm 5.0 \%$ ) , respectively, at the locations of the observations. Improved agreement between modeled and observed $\Delta^{17} \mathrm{O}$ (nitrate) is due to increased importance of ozone versus $\mathrm{HO}_{2}$ and $\mathrm{RO}_{2}$ in $\mathrm{NO}_{x}$ cycling and an increase in the number and importance of nitrate production pathways that yield high $\Delta^{17} \mathrm{O}$ (nitrate) values. The former may be due to implementation of tropospheric reactive halogen chemistry in the model, which impacts ozone and $\mathrm{HO}_{x}$ abundances. The latter is due mainly to increases in the relative importance of $\mathrm{N}_{2} \mathrm{O}_{5}$ hydrolysis, with the hydrolysis of halogen nitrates also playing an important role in remote regions.

The main nitrate formation pathways in the model below $1 \mathrm{~km}$ altitude are from $\mathrm{NO}_{2}+\mathrm{OH}$ and $\mathrm{N}_{2} \mathrm{O}_{5}$ hydrolysis (both $41 \%$ ). The relative importance of global nitrate formation from the hydrolysis of halogen nitrates and hydrogenabstraction reactions involving the nitrate radical $\left(\mathrm{NO}_{3}\right)$ is of similar magnitude $(\sim 5 \%)$. The formation of nitrate from the hydrolysis of organic nitrate has increased slightly in the US and decreased in China (changes $<10 \%$ ) due to changing $\mathrm{NO}_{x}$ emissions from the year 2000 to 2015, although the global mean fractional importance $(6 \%)$ remains unchanged as the regional changes counteract one another. $\mathrm{Ni}$ trate formation via heterogeneous $\mathrm{NO}_{2}$ and $\mathrm{NO}_{3}$ uptake and $\mathrm{NO}_{2}+\mathrm{HO}_{2}$ are negligible $(<2 \%)$. Although aerosol nitrate photolysis has important implications for $\mathrm{O}_{3}$ and $\mathrm{OH}$, the impacts on nitrate formation pathways are small. 
The model parameterization for heterogeneous uptake of $\mathrm{NO}_{2}$ has significant impacts on $\mathrm{HONO}$ and oxidants $(\mathrm{OH}$ and ozone) in the model. HONO production from this reaction has been suggested to be an important source of $\mathrm{OH}$ in Chinese haze due to high $\mathrm{NO}_{x}$ and aerosol abundances (Hendrick et al., 2014; Tong et al., 2016; Wang et al., 2017), with implications for the gas-phase formation of sulfate aerosol from the oxidation of sulfur dioxide by $\mathrm{OH}$ (Shao et al., 2019; Li et al., 2018b). More recent laboratory studies suggest that the reaction probability of $\mathrm{NO}_{2}$ on aerosols is lower than that previously used in the model. Using an $\mathrm{NO}_{2}$ reaction probability formulation that depends on the chemical composition of aerosols as described in Holmes et al. (2019) renders this reaction negligible for nitrate formation and has significant implications for modeled $\mathrm{HONO}$, ozone, and $\mathrm{OH}$. Although uncertainty also exists in the relative yield of nitrate and HONO from this reaction, the impacts of this assumption are negligible when we use these updated $\mathrm{NO}_{2}$ reaction probabilities. Observations of $\Delta^{17} \mathrm{O}$ (nitrate) in Chinese haze events during winter (He et al., 2018b) may help to quantify the importance of this nitrate production pathway in a region where the model predicts it is significant.

Data availability. The GEOS-Chem model is available at: https://doi.org/10.5281/zenodo.1343547 (last access: $10 \mathrm{Au}-$ gust 2018).

Supplement. The supplement related to this article is available online at: https://doi.org/10.5194/acp-20-3859-2020-supplement.

Author contributions. BA designed the study and performed the model simulations and calculations. All other authors provided model code and contributed to writing and analysis.

Competing interests. The authors declare that they have no conflict of interest.

Acknowledgements. Becky Alexander acknowledges helpful discussions with Joel Savarino and Ron Cohen.

Financial support. This research has been supported by the NSF AGS (grant nos. 1644998 and 1702266), the NASA New Investigator Program (grant no. NNX16AI57G), and the Australian Research Council (grant no. DP160101598).

Review statement. This paper was edited by Jan Kaiser and reviewed by Greg Michalski and two anonymous referees.

\section{References}

Abbatt, J. P. D. and Waschewsky, G. C. G.: Heterogeneous interactions of $\mathrm{OHBr}, \mathrm{HNO}_{3}, \mathrm{O}_{3}$, and $\mathrm{NO}_{2}$ with deliquescent $\mathrm{NaCl}$ aerosols at room temperature, J. Phys. Chem. A, 102, 37193725, 1998.

Alexander, B., Savarino, J., Kreutz, K. J., and Thiemens, M. H.: Impact of preindustrial biomass-burning emissions on the oxidation pathways of tropospheric sulfur and nitrogen, J. Geophys. Res., 109, D08303, https://doi.org/10.1029/2003JD004218, 2004.

Alexander, B., Hastings, M. G., Allman, D. J., Dachs, J., Thornton, J. A., and Kunasek, S. A.: Quantifying atmospheric nitrate formation pathways based on a global model of the oxygen isotopic composition $\left(\Delta^{17} \mathrm{O}\right)$ of atmospheric nitrate, Atmos. Chem. Phys., 9, 5043-5056, https://doi.org/10.5194/acp-9-5043-2009, 2009.

Atkinson, R.: Atmospheric chemistry of VOCs and $\mathrm{NO}_{x}$, Atmos. Environ., 34, 2063-2101, https://doi.org/10.1016/S13522310(99)00460-4, 2000.

Berhanu, T. A., Savarino, J., Bhattacharya, S. K., and Vicars, W. C.: ${ }^{17} \mathrm{O}$ excess transfer during the $\mathrm{NO}_{2}+\mathrm{O}_{3}->\mathrm{NO}_{3}+\mathrm{O}_{2}$ reaction, J. Chem. Phys., 136, 044311, https://doi.org/10.1063/1.3666852, 2012.

Bertram, T. H. and Thornton, J. A.: Toward a general parameterization of $\mathrm{N}_{2} \mathrm{O}_{5}$ reactivity on aqueous particles: the competing effects of particle liquid water, nitrate and chloride, Atmos. Chem. Phys., 9, 8351-8363, https://doi.org/10.5194/acp-9-8351-2009, 2009.

Bey, I., Jacob, D. J., Yantosca, R. M., Logan, J. A., Field, B. D., Fiore, A. M., Li, Q., Liu, H. Y., Mickley, L. J., and Schultz, M. G.: Global modeling of tropospheric chemistry with assimilated meteorology: Model description and evaluation, J. Geophys. Res., 106, 23073-23095, 2001.

Bhattacharya, S. K., Pandey, A., and Savarino, J.: Determination of intramolecular isotope distribution of ozone by oxidation reaction with silver metal, J. Geophys. Res, 113, D03303, https://doi.org/10.1029/2006JF008309, 2008.

Bhattacharya, S. K., Savarino, J., Michalski, G., and Liang, M.-C.: A new feature in the internal heavy isotope distribution in ozone, J. Chem. Phys., 141, 134301, https://doi.org/10.1063/1.4895614, 2014.

Brenninkmeijer, C. A. M., Janssen, C., Kaiser, J., Rockmann, T., Rhee, T. S., and Assonov, S. S.: Isotope effects in the chemistry of atmospheric trace compounds, Chem. Rev., 102, 5125-5161, 2003.

Bröske, R., Kleffmann, J., and Wiesen, P.: Heterogeneous conversion of $\mathrm{NO}_{2}$ on secondary organic aerosol surfaces: A possible source of nitrous acid (HONO) in the atmosphere?, Atmos. Chem. Phys., 3, 469-474, https://doi.org/10.5194/acp-3469-2003, 2003.

Brothers, L. A., Dominguez, G., Fabian, P., and Thiemens, M. H.: Using multi-isotope tracer methods to understand the sources of nitrate in aerosols, fog and river water in Podocarpus National Forest, Ecuador, Eos Trans. AGU, 89, Abstract A11C0136, 2008.

Browne, E. C. and Cohen, R. C.: Effects of biogenic nitrate chemistry on the $\mathrm{NO}_{x}$ lifetime in remote continental regions, Atmos. Chem. Phys., 12, 11917-11932, https://doi.org/10.5194/acp-1211917-2012, 2012. 
Burkholder, J. B., Sander, S. P., Abbatt, J. P. D., Barker, J. R., Huie, R. E., Kolb, C. E., Kurylo, M. J., Orkin, V. L., Wilmouth, D. M., and Wine, P. H.: Chemical kinetics and photochemical data for use in atmospheric studies: evaluation number 18, Jet Propulsion Laboratory, Pasadena, CA, 1392 pp., 2015.

Butkovskaya, N. I., Kukui, A., Pouvesle, N., and Le Bras, G.: Formation of Nitric Acid in the Gas-Phase $\mathrm{HO}_{2}+\mathrm{NO}$ Reaction: Effects of Temperature and Water Vapor, J. Phys. Chem. A, 109, 6509-6520, https://doi.org/10.1021/jp051534v, 2005.

Chen, Q., Schmidt, J. A., Shah, V., Jaeglé, L., Sherwen, T., and Alexander, B.: Sulfate production by reactive bromine: Implications for the global sulfur and reactive bromine budgets, Geophys. Res. Lett., 44, 7069-7078, https://doi.org/10.1002/2017GL073812, 2017.

Chen, Q., Edebeli, J., McNamara, S. M., Kulju, K., May, N. W., Bertman, S. P., Thanekar, S., Fuentes, J. D., and Pratt, K. A.: HONO, Particulate Nitrite, and Snow Nitrite at a Midlatitude Urban Site during Wintertime, ACS Earth Space Chem., 3, 811822, https://doi.org/10.1021/acsearthspacechem.9b00023, 2019.

Connell, P. and Johnston, H. S.: Thermal dissociation of $\mathrm{N}_{2} \mathrm{O}_{5}$ in $\mathrm{N}_{2}$, Geophys. Res. Lett., 6, 553-556, 1979.

Costa, A. W., Michalski, G., Schauer, A. J., Alexander, B., Steig, E. J., and Shepson, P. B.: Analysis of atmospheric inputs of nitrate to a temperate forest ecosystem from $\Delta^{17} \mathrm{O}$ isotope ratio measurements, Geophys. Res. Lett., 38, L15805, https://doi.org/10.1029/2011GL047539, 2011.

Crowley, J. N., Ammann, M., Cox, R. A., Hynes, R. G., Jenkin, M. E., Mellouki, A., Rossi, M. J., Troe, J., and Wallington, T. J.: Evaluated kinetic and photochemical data for atmospheric chemistry: Volume $\mathrm{V}$ - heterogeneous reactions on solid substrates, Atmos. Chem. Phys., 10, 9059-9223, https://doi.org/10.5194/acp-10-9059-2010, 2010.

Domine, F. and Shepson, P. B.: Air-Snow Interactions and Atmospheric Chemistry, Science, 297, 1506-1510, https://doi.org/10.1126/science.1074610, 2002.

Dubey, M. K., Mohrschladt, R., Donahue, N. M., and Anderson, J. G.: Isotope-specific kinetics of hydroxyl radical $(\mathrm{OH})$ with water $\left(\mathrm{H}_{2} \mathrm{O}\right)$ : Testing models of reactivity and atmospheric fractionation, J. Phys. Chem. A, 101, 1494-1500, 1997.

Evans, M. J. and Jacob, D. J.: Impact of new laboratory studies of $\mathrm{N}_{2} \mathrm{O}_{5}$ hydrolysis on global model budgets of tropospheric nitrogen oxides, ozone, and OH, Geophys. Res. Lett., 32, L09813, https://doi.org/10.1029/2005GL022469, 2005.

Ewing, S. A., Michalski, G., Thiemens, M., Quinn, R. C., Macalady, J. L., Kohl, S., Wankel, S. D., Kendall, C., McKay, C. P., and Amundson, R.: Rainfall limit of the $\mathrm{N}$ cycle on Earth, Global Biogeochem. Cy., 21, GB3009, https://doi.org/10.1029/2006gb002838, 2007.

Fibiger, D. L., Hastings, M. G., Dibb, J. E., and Huey, L. G.: The preservations of atmospheric nitrate in snow at Summit, Greenland, Geophys. Res. Lett., 40, 3484-3489, https://doi.org/10.1002/grl.50659, 2013.

Finlayson-Pitts, B. J., Wingen, L. M., Sumner, A. L., Syomin, D., and Ramazan, K. A.: The heterogeneous hydrolysis of $\mathrm{NO}_{2}$ in laboratory systems and in outdoor and indoor atmospheres: An integrated mechanism, Phys. Chem. Chem. Phys., 5, 223-242, 2003

Fisher, J. A., Jacob, D. J., Travis, K. R., Kim, P. S., Marais, E. A., Chan Miller, C., Yu, K., Zhu, L., Yantosca, R. M., Sul- prizio, M. P., Mao, J., Wennberg, P. O., Crounse, J. D., Teng, A. P., Nguyen, T. B., St. Clair, J. M., Cohen, R. C., Romer, P., Nault, B. A., Wooldridge, P. J., Jimenez, J. L., CampuzanoJost, P., Day, D. A., Hu, W., Shepson, P. B., Xiong, F., Blake, D. R., Goldstein, A. H., Misztal, P. K., Hanisco, T. F., Wolfe, G. M., Ryerson, T. B., Wisthaler, A., and Mikoviny, T.: Organic nitrate chemistry and its implications for nitrogen budgets in an isoprene- and monoterpene-rich atmosphere: constraints from aircraft $\left(\mathrm{SEAC}^{4} \mathrm{RS}\right)$ and ground-based (SOAS) observations in the Southeast US, Atmos. Chem. Phys., 16, 5969-5991, https://doi.org/10.5194/acp-16-5969-2016, 2016.

Fisher, J. A., Atlas, E. L., Barletta, B., Meinardi, S., Blake, D. R., Thompson, C. R., Ryerson, T. B., Peischl, J., Tzompa-Sosa, Z. A., and Murray, L. T.: Methyl, Ethyl, and Propyl Nitrates: Global Distribution and Impacts on Reactive Nitrogen in Remote Marine Environments, J. Geophys. Res., 123, 12429-12451, https://doi.org/10.1029/2018JD029046, 2018.

Fountoukis, C. and Nenes, A.: ISORROPIA II: a computationally efficient thermodynamic equilibrium model for $\mathrm{K}^{+}$. $\mathrm{Ca}^{2+}-\mathrm{Mg}^{2+}-\mathrm{NH}_{4}^{+}-\mathrm{Na}^{+}-\mathrm{SO}_{4}^{2-}-\mathrm{NO}_{3}^{-}-\mathrm{Cl}^{-}-\mathrm{H}_{2} \mathrm{O}$ aerosols, Atmos. Chem. Phys., 7, 4639-4659, https://doi.org/10.5194/acp-74639-2007, 2007.

Geng, L., Cole-Dai, J., Alexander, B., Erbland, J., Savarino, J., Schauer, A. J., Steig, E. J., Lin, P., Fu, Q., and Zatko, M. C.: On the origin of the occasional spring nitrate peak in Greenland snow, Atmos. Chem. Phys., 14, 13361-13376, https://doi.org/10.5194/acp-14-13361-2014, 2014.

Geng, L., Murray, L. T., Mickley, L. J., Lin, P., Fu, Q., Schauer, A. J., and Alexander, B.: Isotopic evidence of multiple controls on atmospheric oxidants over climate transitions, Nature, 546, 133 136, https://doi.org/10.1038/nature22340, 2017.

Guha, T., Lin, C. T., Bhattacharya, S. K., Mahajan, A. S., OuYang, C.-F., Lan, Y.-P., Hsu, S. C., and Liang, M.-C.: Isotopic ratios of nitrate in aerosol samples from Mt. Lulin, a highaltitude station in Central Taiwan, Atmos. Environ., 154, 53-69, https://doi.org/10.1016/j.atmosenv.2017.01.036, 2017.

Guo, H., Weber, R. J., and Nenes, A.: High levels of ammonia do not raise fine particle $\mathrm{pH}$ sufficiently to yield nitrogen oxide-dominated sulfate production, Sci. Rep., 7, 1-7, https://doi.org/10.1038/s41598-017-11704-0, 2017.

Gustafsson, R. J., Kyiakou, G., and Lambert, R. M.: The molecular methanism of tropospheric nitrous acid production on mineral dust surfaces, Chem. Phys. Chem., 9, 1390-1393, https://doi.org/10.1002/cphc.200800259, 2009.

Gutzwiller, L., George, C., Rossler, E., and Ammann, J.: Reaction Kinetics of $\mathrm{NO}_{2}$ with Resorcinol and 2,7-Naphthalenediol in the Aqueous Phase at Different pH, J. Phys. Chem. A, 106, 12045 12050, https://doi.org/10.1021/jp026240d, 2002.

Hastings, M. G., Sigman, D. M., and Lipschultz, F.: Isotopic evidence for source changes of nitrate in rain at Bermuda, J. Geophys. Res., 108, 4790, https://doi.org/10.1029/2003JD003789, 2003.

He, P., Alexander, B., Geng, L., Chi, X., Fan, S., Zhan, H., Kang, H., Zheng, G., Cheng, Y., Su, H., Liu, C., and Xie, Z.: Isotopic constraints on heterogeneous sulfate production in Beijing haze, Atmos. Chem. Phys., 18, 5515-5528, https://doi.org/10.5194/acp18-5515-2018, 2018a.

He, P., Xie, Z., Chi, X., Yu, X., Fan, S., Kang, H., Liu, C., and Zhan, H.: Atmospheric $\Delta^{17} \mathrm{O}\left(\mathrm{NO}_{3}^{-}\right)$reveals nocturnal chem- 
istry dominates nitrate production in Beijing haze, Atmos. Chem. Phys., 18, 14465-14476, https://doi.org/10.5194/acp-18-144652018, 2018b.

Heidenreich, J. E. and Thiemens, M. H.: A non-mass dependent oxygen isotope effect in the production of ozone from molecular oxygen: The role of molecular symmetry in isotope chemistry, J. Chem. Phys., 84, 2129-2136, 1986.

Hendrick, F., Müller, J.-F., Clémer, K., Wang, P., De Mazière, M., Fayt, C., Gielen, C., Hermans, C., Ma, J. Z., Pinardi, G., Stavrakou, T., Vlemmix, T., and Van Roozendael, M.: Four years of ground-based MAX-DOAS observations of HONO and $\mathrm{NO}_{2}$ in the Beijing area, Atmos. Chem. Phys., 14, 765-781, https://doi.org/10.5194/acp-14-765-2014, 2014.

Hoesly, R. M., Smith, S. J., Feng, L., Klimont, Z., JanssensMaenhout, G., Pitkanen, T., Seibert, J. J., Vu, L., Andres, R. J., Bolt, R. M., Bond, T. C., Dawidowski, L., Kholod, N., Kurokawa, J.-I., Li, M., Liu, L., Lu, Z., Moura, M. C. P., O'Rourke, P. R., and Zhang, Q.: Historical (1750-2014) anthropogenic emissions of reactive gases and aerosols from the Community Emissions Data System (CEDS), Geosci. Model Dev., 11, 369-408, https://doi.org/10.5194/gmd-11-369-2018, 2018.

Holmes, C. D., Prather, M. J., and Vinken, G. C. M.: The climate impact of ship $\mathrm{NO}_{x}$ emissions: an improved estimate accounting for plume chemistry, Atmos. Chem. Phys., 14, 6801-6812, https://doi.org/10.5194/acp-14-6801-2014, 2014.

Holmes, C. D., Bertram, T. H., Confer, K. L., Graham, K. A., Ronan, A. C., Wirks, C. K., and Shah, V.: The role of clouds in the tropospheric $\mathrm{NO}_{x}$ cycle: a new modeling approach for cloud chemistry and its global implications, Geophys. Res. Lett., 46, GL081990, https://doi.org/10.1029/2019GL081990, 2019.

Horowitz, L. W., Fiore, A. M., Milly, G. P., Cohen, R. C., Perring, A., Wooldridge, P. J., Hess, P. G., Emmons, L. K., and Lamarque, J.-F.: Observational constraints on the chemistry of isoprene nitrates over the eastern United States, J. Geophys. Res, 112, D12S08, https://doi.org/10.1029/2006JD007747, 2007.

Hudman, R. C., Moore, N. E., Mebust, A. K., Martin, R. V., Russell, A. R., Valin, L. C., and Cohen, R. C.: Steps towards a mechanistic model of global soil nitric oxide emissions: implementation and space based-constraints, Atmos. Chem. Phys., 12, 7779-7795, https://doi.org/10.5194/acp-12-7779-2012, 2012.

Ishino, S., Hattori, S., Savarino, J., Jourdain, B., Preunkert, S., Legrand, M., Caillon, N., Barbero, A., Kuribayashi, K., and Yoshida, N.: Seasonal variations of triple oxygen isotopic compositions of atmospheric sulfate, nitrate, and ozone at Dumont d'Urville, coastal Antarctica, Atmos. Chem. Phys., 17, 37133727, https://doi.org/10.5194/acp-17-3713-2017, 2017.

Jacob, D. J.: Heterogeneous chemistry and tropospheric ozone, Atmos. Environ., 34, 2131-2159, 2000.

Jacobs, M. I., Burke, W. J., and Elrod, M. J.: Kinetics of the reactions of isoprene-derived hydroxynitrates: gas phase epoxide formation and solution phase hydrolysis, Atmos. Chem. Phys., 14, 8933-8946, https://doi.org/10.5194/acp-14-8933-2014, 2014.

Jaeglé, L., Steinberger, L., Martin, R. V., and Chance, K.: Global partitioning of $\mathrm{NO}_{x}$ sources using satellite observations: Relative roles of fossil fuel combustion, biomass burning and soil emissions, Faraday Discuss., 130, 407-423, https://doi.org/10.1039/b502128f, 2005.

Jaeglé, L., Shah, V., Thornton, J. A., Lopez-Hilfiker, F. D., Lee, B. H., McDuffie, E. E., Fibiger, D., Brown, S. S., Veres, P., Sparks,
T. L., Ebben, C. J., Wooldridge, P. J., Kenagy, H. S., Cohen, R. C., Weinheimer, A. J., Campos, T. L., Montzka, D. D., Digangi, J. P., Wolfe, G. M., Hanisco, T., Schroder, J. C., CampuzanoJost, P., Day, D. A., Jimenez, J. L., Sullivan, A. P., Guo, H., and Weber, R. J.: Nitrogen oxides emissions, chemistry, deposition, and export over the Northeast United States during the WINTER aircraft campaign, J. Geophys. Res., 123, 12368-12393, doi.org/10.1029/2018JD029133, 2018.

Jenkin, M. E., Cox, R. A., and Williams, D. J.: Laboratory studies of the kinetics of formation of nitrous acid from the thermal reaction of nitrogen dioxide and water vapor, Atmos. Environ., 22, 487498, 1988.

Johnston, J. C. and Thiemens, M. H.: The isotopic composition of tropospheric ozone in three environments, J. Geophys. Res., 102, 25395-25404, 1997.

Kaiser, J., Hastings, M. G., Houlton, B. Z., Rockmann, T., and Sigman, D. M.: Triple Oxygen Isotope Analysis of Nitrate Using the Denitrifier Method and Thermal Decomposition of $\mathrm{N}_{2} \mathrm{O}$, Anal. Chem., 79, 599-607, 2007.

Kasibhatla, P., Sherwen, T., Evans, M. J., Carpenter, L. J., Reed, C., Alexander, B., Chen, Q., Sulprizio, M. P., Lee, J. D., Read, K. A., Bloss, W., Crilley, L. R., Keene, W. C., Pszenny, A. A. P., and Hodzic, A.: Global impact of nitrate photolysis in sea-salt aerosol on $\mathrm{NO}_{x}, \mathrm{OH}$, and $\mathrm{O}_{3}$ in the marine boundary layer, Atmos. Chem. Phys., 18, 11185-11203, https://doi.org/10.5194/acp-18 11185-2018, 2018.

Krankowsky, D., Bartecki, F., Klees, G. G., Mauersberger, K., Schellenback, K., and Stehr, J.: Measurement of heavy isotope enrichment in tropospheric ozone, Geophys. Res. Lett., 22, 1713-1716, 1995.

Krankowsky, D., Lammerzahl, P., and Mauersberger, K.: Isotopic measurements of stratospheric ozone, Geophys. Res. Lett., 27, 2593-2595, 2000.

Kunasek, S. A., Alexander, B., Hastings, M. G., Steig, E. J., Gleason, D. J., and Jarvis, J. C.: Measurements and modeling of $\Delta^{17} \mathrm{O}$ of nitrate in a snowpit from Summit, Greenland, J. Geophys. Res., 113, D24302, https://doi.org/10.1029/2008JD010103, 2008.

Lee, C., Martin, R. V., van Donkelaar, A., Lee, H., Dickerson, R. R., Hains, J. C., Krotkov, N., Richter, A., innikov, K., and Schwab, J. J.: $\mathrm{SO}_{2}$ emissions and lifetimes: Estimates from inverse modeling using in situ and global, space-based (SCIAMACHY and OMI) observations, J. Geophys. Res., 116, D06304, https://doi.org/10.1029/2010JD014758, 2011.

Lee, H.-M., Henze, D. K., Alexander, B., and Murray, L. T.: Investigating the sensitivity of surface-level nitrate seasonality in Antarctica to primary sources using a global model, Atmos. Environ., 89, 757-767, https://doi.org/10.1016/j.atmosenv.2014.03.003, 2014.

Lee, J. H. and Tang, I. N.: Accommodation coefficient of gaseous $\mathrm{NO}_{2}$ on water surfaces, Atmos. Environ., 22, 1147-1151, 1988.

Levy, H., Moxim, W. J., Klonecki, A. A., and Kasibhatla, P. S.: Simulated tropospheric $\mathrm{NO}_{x}$ : Its evaluation, global distribution and individual source contributions, J. Geophys. Res, 104, 26279 226306, 1999.

Li, L., Duan, Z., Li, H., Zhu, C., Henkelman, G., Francisco, J. S., and Zeng, X. C.: Formation of HONO from the $\mathrm{NH}_{3}$-promoted hydrolysis of $\mathrm{NO}_{2}$ dimers in the 
atmosphere, P. Natl. Acad. Sci. USA, 115, 7236-7241, https://doi.org/10.1073/pnas.1807719115, 2018a.

Li, L., Hoffmann, M. R., and Colussi, A. J.: Role of Nitrogen Dioxide in the Production of Sulfate during Chinese Haze-Aerosol Episodes, Environ. Sci. Technol., 52, 2686-2693, https://doi.org/10.1021/acs.est.7b05222, 2018b.

Li, M., Zhang, Q., Kurokawa, J.-I., Woo, J.-H., He, K., Lu, Z., Ohara, T., Song, Y., Streets, D. G., Carmichael, G. R., Cheng, Y., Hong, C., Huo, H., Jiang, X., Kang, S., Liu, F., Su, H., and Zheng, B.: MIX: a mosaic Asian anthropogenic emission inventory under the international collaboration framework of the MICS-Asia and HTAP, Atmos. Chem. Phys., 17, 935-963, https://doi.org/10.5194/acp-17-935-2017, 2017.

Liang, J., Horowitz, L. W., Jacob, D. J., Wang, Y., Fiore, A. M., Logan, J. A., Gardner, G. M., and Munger, J. W.: Seasonal budgets of reactive nitrogen species and ozone over the United States, and export fluxes to the global atmosphere, J. Geophys. Res., 103, 13435-13450,, 1998.

Liu, H., Jacob, D. J., Bey, I., and Yantosca, R. M.: Constraints from ${ }^{210} \mathrm{~Pb}$ and ${ }^{7} \mathrm{Be}$ on wet deposition and transport in a global threedimensional chemical tracer model driven by assimilated meteorological fields, J. Geophys. Res., 106, 12109-12128, 2001.

Long, M. S., Keene, W. C., Easter, R. C., Sander, R., Liu, X., Kerkweg, A., and Erickson, D.: Sensitivity of tropospheric chemical composition to halogen-radical chemistry using a fully coupled size-resolved multiphase chemistry-global climate system: halogen distributions, aerosol composition, and sensitivity of climate-relevant gases, Atmos. Chem. Phys., 14, 3397-3425, https://doi.org/10.5194/acp-14-3397-2014, 2014.

Lyons, J. R.: Transfer of mass-independent fractioation on ozone to other oxygen-containing molecules in the atmosphere, Geophys. Res. Lett., 28, 3231-3234, 2001.

Macintyre, H. L. and Evans, M. J.: Sensitivity of a global model to the uptake of $\mathrm{N}_{2} \mathrm{O}_{5}$ by tropospheric aerosol, Atmos. Chem. Phys., 10, 7409-7414, https://doi.org/10.5194/acp10-7409-2010, 2010.

Martin, R. V., Jacob, D. J., Yantosca, R. M., Chin, M., and Ginoux, P.: Global and regional decreases in tropospheric oxidants form photochemical effects of aerosols, J. Geophys. Res., 108, 4097, doi:4010.1029/2002JD002622, 2003.

Mauersberger, K., Lämmerzahl, P., and Krankowsky, D.: Stratospheric Ozone Isotope Enrichments - Revisited, Geophys. Res. Lett., 28, 3155-3158, 2001.

McCabe, J. R., Boxe, C. S., Colussi, A. J., Hoffmann, M. R., and Thiemens, M. H.: Oxygen isotopic fractionation in the photochemistry of nitrate in water and ice, J. Geophys. Res., 110, D15310, https://doi.org/10.1029/2004JD005484, 2005.

McCabe, J. R., Savarino, J., Alexander, B., Gong, S., and Thiemens, M. H.: Isotopic constraints on non-photochemical sulfate production in the Arctic winter, Geophys. Res. Lett., 33, L05810, https://doi.org/10.1029/2005GL025164, 2006.

McCabe, J. R., Thiemens, M. H., and Savarino, J.: A record of ozone variability in South Pole Antarctic snow: Role of nitrate oxygen isotopes, J. Geophys. Res, 112, D12303, https://doi.org/10.1029/2006JD007822, 2007.

Michalski, G. and Bhattacharya, S. K.: The role of symmetry in the mass independent isotope effect in ozone, P. Natl. Acad. Sci. USA, 106, 5493-5496, 2009.
Michalski, G., Bhattacharya, S. K., and Girsch, G.: NO $\mathrm{NO}_{x}$ cycle and the tropospheric ozone isotope anomaly: an experimental investigation, Atmos. Chem. Phys., 14, 4935-4953, https://doi.org/10.5194/acp-14-4935-2014, 2014.

Michalski, G. M., Scott, Z., Kabiling, M., and Thiemens, M. H.: First measurements and modeling of $\Delta^{17} \mathrm{O}$ in atmospheric nitrate, Geophys. Res. Lett., 30, 1870 , doi:1810.1029/2003GL017015, 2003.

Morin, S., Savarino, J., Bekki, S., Gong, S., and Bottenheim, J. W.: Signature of Arctic surface ozone depletion events in the isotope anomaly $\left(\Delta^{17} \mathrm{O}\right)$ of atmospheric nitrate, Atmos. Chem. Phys., 7, 1451-1469, https://doi.org/10.5194/acp-7-1451-2007, 2007.

Morin, S., Savarino, J., Frey, M. M., Yan, N., Bekki, S., Bottenheim, J. W., and Martins, J. M. F.: Tracing the Origin and Fate of $\mathrm{NO}_{x}$ in the Arctic Atmosphere Using Stable Isotopes in Nitrate, Science, 322, 730-732, https://doi.org/10.1126/science.1161910, 2008.

Morin, S., Savarino, J., Frey, M. M., Dominé, F., Jacobi, H.-W., Kaleschke, L., and Martins, J. M. F.: Comprehensive isotopic composition of atmospheric nitrate in the Atlantic Ocean boundary layer from $65^{\circ} \mathrm{S}$ to $79^{\circ} \mathrm{N}, \mathrm{J}$. Geophys. Res, 114, D05303, https://doi.org/10.1029/2008JD010696, 2009.

Morin, S., Sander, R., and Savarino, J.: Simulation of the diurnal variations of the oxygen isotope anomaly $\left(\Delta^{17} \mathrm{O}\right)$ of reactive atmospheric species, Atmos. Chem. Phys., 11, 3653-3671, https://doi.org/10.5194/acp-11-3653-2011, 2011.

Morton, J., Barnes, J., Schueler, B., and Mauersberger, K.: Laboratory studies of heavy ozone, J. Geophys. Res., 95, 901-907, 1990.

Müller, J.-F., Peeters, J., and Stavrakou, T.: Fast photolysis of carbonyl nitrates from isoprene, Atmos. Chem. Phys., 14, 2497 2508, https://doi.org/10.5194/acp-14-2497-2014, 2014.

Murray, L. T., Jacob, D. J., Logan, J. A., Hudman, R. C., and Koshak, W. J.: Optimized regional and interannual variability of lightning in a global chemical transport model constrained by LIS/OTD satellite data, J. Geophys. Res., 117, D20307, https://doi.org/10.1029/2012JD017934, 2012.

Murray, L. T.: Lightning $\mathrm{NO}_{x}$ and Impacts on Air Quality, Curr. Pollution Rep., 2, 115-133, https://doi.org/10.1007/s40726-0160038-0, 2016.

Newsome, B. and Evans, M.: Impact of uncertainties in inorganic chemical rate constants on tropospheric composition and ozone radiative forcing, Atmos. Chem. Phys., 17, 14333-14352, https://doi.org/10.5194/acp-17-14333-2017, 2017.

O’Brien, J., Shepson, P., Muthuramu, K., Hao, C., Niki, H., Hastie, D., Taylor, R., and Roussel, P.: Measurements of alkyl and multifunctional organic nitrates at a rural site in Ontario, J. Geophys. Res., 100, 22795-22804, 1995.

Park, R. J., Jacob, D. J., Field, B. D., Yantosca, R. M., and Chin, M.: Natural and transboundary pollution influences on sulfate-nitrate-ammonium aerosols in the United States: implications for policy, J. Geophys. Res., 109, D15204, https://doi.org/10.1029/2003JD004473, 2004.

Parrella, J. P., Jacob, D. J., Liang, Q., Zhang, Y., Mickley, L. J., Miller, B., Evans, M. J., Yang, X., Pyle, J. A., Theys, N., and Van Roozendael, M.: Tropospheric bromine chemistry: implications for present and pre-industrial ozone and mercury, Atmos. Chem. Phys., 12, 6723-6740, https://doi.org/10.5194/acp12-6723-2012, 2012. 
Paulot, F., Crounse, J. D., Kjaergaard, H. G., Kroll, J. H., Seinfeld, J. H., and Wennberg, P. O.: Isoprene photooxidation: new insights into the production of acids and organic nitrates, Atmos. Chem. Phys., 9, 1479-1501, 2009.

Ramazan, K. A., Syomin, D., and Finlayson-Pitts, B. J.: The photochemical production of HONO during the heterogeneous hydrolysis of $\mathrm{NO}_{2}$, Phys. Chem. Chem. Phys., 6, 3836-3843, https://doi.org/10.1039/b402195a, 2004.

Reed, C., Evans, M. J., Crilley, L. R., Bloss, W. J., Sherwen, T., Read, K. A., Lee, J. D., and Carpenter, L. J.: Evidence for renoxification in the tropical marine boundary layer, Atmos. Chem. Phys., 17, 4081-4092, https://doi.org/10.5194/acp17-4081-2017, 2017.

Richter, A., Borrows, J. P., Nub, H., Granier, C., and Niemier, U.: Increase in tropospheric nitrogen dioxide over China observed from space, Nature, 437, 129-132, https://doi.org/10.1038/nature04092, 2005.

Rindelaub, J. D., McAvey, K. M., and Shepson, P. B.: The photochemical production of organic nitrates from $\alpha$-pinene and loss via acid-dependent particle phase hydrolysis,, Atmos. Environ., 193-201, https://doi.org/10.1016/j.atmosenv.2014.11.010, 2015.

Romer, P. S., Wooldridge, P. J., Crounse, J. D., Kim, M. J., Wennberg, P. O., Dibb, J. E., Scheuer, E., Blake, D. R., Meinardi, S., Brosius, A. L., Thames, A. B., Miller, D. O., Brune, W. H., Hall, S. R., Ryerson, T. B., and Cohen, R. C.: Constraints on Aerosol Nitrate Photolysis as a Potential Source of HONO and $\mathrm{NO}_{x}$, Environ. Sci. Technol., 52, 13738-13746, https://doi.org/10.1021/acs.est.8b03861, 2018.

Saiz-Lopez, A., Lamarque, J.-F., Kinnison, D. E., Tilmes, S., Ordóñez, C., Orlando, J. J., Conley, A. J., Plane, J. M. C., Mahajan, A. S., Sousa Santos, G., Atlas, E. L., Blake, D. R., Sander, S. P., Schauffler, S., Thompson, A. M., and Brasseur, G.: Estimating the climate significance of halogen-driven ozone loss in the tropical marine troposphere, Atmos. Chem. Phys., 12, 3939-3949, https://doi.org/10.5194/acp-12-3939-2012, 2012.

Savarino, J. and Thiemens, M. H.: Analytical procedure to determine both $\delta^{18} \mathrm{O}$ and $\delta^{17} \mathrm{O}$ of $\mathrm{H}_{2} \mathrm{O}_{2}$ in natural water and first measurements, Atmos. Environ., 33, 3683-3690, $1999 \mathrm{~b}$.

Savarino, J., Kaiser, J., Morin, S., Sigman, D. M., and Thiemens, M. H.: Nitrogen and oxygen isotopic constraints on the origin of atmospheric nitrate in coastal Antarctica, Atmos. Chem. Phys., 7, 1925-1945, https://doi.org/10.5194/acp-7-1925-2007, 2007.

Savarino, J., Bhattacharya, S. K., Morin, S., Baroni, M., and Doussin, J.-F.: The $\mathrm{NO}+\mathrm{O}_{3}$ reaction: A triple oxygen isotope perspective on the reaction dynamics and atmospheric implications for the transfer of the ozone isotope anomaly, J. Chem. Phys., 128, 194303, https://doi.org/10.1063/1.2917581, 2008.

Savarino, J., Morin, S., Erbland, J., Grannec, F., Patey, M., Vicars, W., Alexander, B., and Achterberg, E. P.: Isotopic composition of atmospheric nitrate in a tropical marine boundary layer, P. Natl. Acad. Sci. USA, 110, 17668-17673, https://doi.org/10.1073/pnas.1216639110, 2013.

Schmidt, J. A., Jacob, D. J., Horowitz, H. M., Hu, L., Sherwen, T., Evans, M. J., Liang, Q., Sulieman, R. M., Oram, D. E., Le Breton, M., Percival, C. J., Wang, S., Dix, B., and Volkamer, R.: Modeling the observed tropospheric BrO background: Importance of multiphase chemistry and implications for ozone, OH, and mercury, J. Geophys. Res., 121, 11819-11835, https://doi.org/10.1002/2015JD024229, 2016.
Shah, V., Jaeglé, L., Thornton, J. A., Lopez-Hilfiker, F. D., Lee, B. H., Schroder, J. C., Campuzano-Jost, P., Jimenez, J. L., Guo, H., Sullivan, A. P., Weber, R. J., Green, J. R., Fiddler, M. N., Bililign, S., Campos, T. L., Stell, M., Weinheimer, A. J., Montzka, D. D., and Brown, S. S.: Chemical feedbacks weaken the wintertime response of particulate sulfate and nitrate to emissions reductions over the eastern United States, P. Natl. Acad. Sci. USA, 115, 8110-8115, https://doi.org/10.1073/pnas.1803295115, 2018.

Shao, J., Chen, Q., Wang, Y., Lu, X., He, P., Sun, Y., Shah, V., Martin, R. V., Philip, S., Song, S., Zhao, Y., Xie, Z., Zhang, L., and Alexander, B.: Heterogeneous sulfate aerosol formation mechanisms during wintertime Chinese haze events: air quality model assessment using observations of sulfate oxygen isotopes in Beijing, Atmos. Chem. Phys., 19, 6107-6123, https://doi.org/10.5194/acp-19-6107-2019, 2019.

Sharma, H. D., Jervis, R. E., and Wing, K. Y.: Isotopic exchange reactions in nitrogen oxides, J. Phys. Chem., 74, 923-933, 1970.

Sherwen, T., Schmidt, J. A., Evans, M. J., Carpenter, L. J., Großmann, K., Eastham, S. D., Jacob, D. J., Dix, B., Koenig, T. K., Sinreich, R., Ortega, I., Volkamer, R., Saiz-Lopez, A., PradosRoman, C., Mahajan, A. S., and Ordóñez, C.: Global impacts of tropospheric halogens $(\mathrm{Cl}, \mathrm{Br}, \mathrm{I})$ on oxidants and composition in GEOS-Chem, Atmos. Chem. Phys., 16, 12239-12271, https://doi.org/10.5194/acp-16-12239-2016, 2016.

Sherwen, T., Evans, M. J., Sommariva, R., Hollis, L. D. J., Ball, S. M., Monks, P. S., Reed, C., Carpenter, L. J., Lee, J. D., Forster, G., Bandy, B., Reeves, C. E., and Bloss, W. J.: Effects of halogens on European air-quality, Faraday Discuss., 200, 75-100, https://doi.org/10.1039/C7FD00026J, 2017.

Singh, H. B., Herlth, D., O'Hara, D., Zahnle, K., Bradshaw, J. D., Sandholm, S. T., Talbot, R., Crutzen, P. J., and Kanakidou, M.: Relationship of Peroxyacetyl nitrate to active and total odd nitrogen at northern high latitudes: Influence of reservoir species on $\mathrm{NO}_{x}$ and $\mathrm{O}_{3}$, J. Geophys. Res, 97, 16523-16530, 1992.

Sofen, E. D., Alexander, B., Steig, E. J., Thiemens, M. H., Kunasek, S. A., Amos, H. M., Schauer, A. J., Hastings, M. G., Bautista, J., Jackson, T. L., Vogel, L. E., McConnell, J. R., Pasteris, D. R., and Saltzman, E. S.: WAIS Divide ice core suggests sustained changes in the atmospheric formation pathways of sulfate and nitrate since the 19th century in the extratropical Southern Hemisphere, Atmos. Chem. Phys., 14, 5749-5769, https://doi.org/10.5194/acp-14-5749-2014, 2014.

Spataro, F. and Ianniello, A.: Sources of atmospheric nitrous acid: State of the science, current research needs, and future prospects, J. Air Waste Manage., 64, 1232-1250, https://doi.org/10.1080/10962247.2014.952846, 2014.

Stettler, M. E. J., Eastham, S., and Barrett, S. R. H.: Air quality and public health impacts of UK airports, Part I: Emissions, Atmos. Environ., 45, 5415-5424, https://doi.org/10.1016/j.atmosenv.2011.07.012, 2011.

Tan, F., Tong, S., Jing, B., Hou, S., Liu, Q., Li, K., Zhang, Y., and Ge, M.: Heterogeneous reactions of $\mathrm{NO}_{2}$ with $\mathrm{CaCO}_{3}-$ $\left(\mathrm{NH}_{4}\right)_{2} \mathrm{SO}_{4}$ mixtures at different relative humidities, Atmos. Chem. Phys., 16, 8081-8093, https://doi.org/10.5194/acp-168081-2016, 2016.

The International GEOS-Chem User Community: GEOS-Chem 12.0.0, https://doi.org/10.5281/zenodo.1343547, 2018. 
Thiemens, M. H. and Jackson, T.: Pressure dependency for heavy isotope enhancement in ozone formation, Geophys. Res. Lett., 17, 717-719, 1990.

Tong, S. R., Hou, S. Q., Zhang, Y., Chu, B. W., Liu, Y. C., He, H., Zhao, P. S., and Ge, M. F.: Exploring the nitrous acid (HONO) formation mechanism in winter Beijing: direct emissions and heterogeneous production in urban and suburban areas, Faraday Discuss., 189, 213-230, https://doi.org/10.1039/c5fd00163c, 2016.

Vicars, W. and Savarino, J.: Quantitative constraints on the ${ }^{17} \mathrm{O}$ excess $\left(\Delta^{17} \mathrm{O}\right)$ signature of surface ozone: Ambient measurements from $50^{\circ} \mathrm{N}$ to $50^{\circ} \mathrm{S}$ using the nitrite-coated filter technique, Geochem. Cosmochem. Ac., 135, 270-287, https://doi.org/10.1016/j.gca.2014.03.023, 2014.

Vicars, W. C., Bhattacharya, S. K., Erbland, J., and Savarino, J.: Measurement of the ${ }^{17} \mathrm{O}$-excess $\left(\Delta^{17} \mathrm{O}\right)$ of tropospheric ozone using a nitrite-coated filter, Rapid Commun. Mass Spec., 26, 1219-1231, https://doi.org/10.1002/rcm.6218, 2012.

Vinken, G. C. M., Boersma, K. F., Jacob, D. J., and Meijer, E. W.: Accounting for non-linear chemistry of ship plumes in the GEOS-Chem global chemistry transport model, Atmos. Chem. Phys., 11, 11707-11722, https://doi.org/10.5194/acp-11-117072011, 2011.

von Glasow, R. and Crutzen, P. J.: Model study of multiphase DMS oxidation with a focus on halogens, Atmos. Chem. Phys., 4, 589608, https://doi.org/10.5194/acp-4-589-2004, 2004.

Wang, F., Michalski, G., Seo, J., and Ge, W.: Geochemical, isotopic, and mineralogical constraints on atmospheric deposition in the hyper-arid Atacama Desert, Chile, Geochem. Cosmochem. Ac., 135, 29-48, https://doi.org/10.1016/j.gca.2014.03.017, 2014.

Wang, J. Q., Zhang, X. S., Guo, J., Wang, Z. W., and Zhang, M. G.: Observation of nitrous acid (HONO) in Beijing, China: Seasonal variation, nocturnal formation and daytime budget, Sci. Total Environ., 587, https://doi.org/10.1016/j.scitotenv.2017.02.159, 2017.

Wang, X., Jacob, D. J., Eastham, S. D., Sulprizio, M. P., Zhu, L., Chen, Q., Alexander, B., Sherwen, T., Evans, M. J., Lee, B. H., Haskins, J. D., Lopez-Hilfiker, F. D., Thornton, J. A., Huey, G. L., and Liao, H.: The role of chlorine in global tropospheric chemistry, Atmos. Chem. Phys., 19, 3981-4003, https://doi.org/10.5194/acp-19-3981-2019, 2019.

Wang, Y. H., Jacob, D. J., and Logan, J. A.: Global simulation of tropospheric $\mathrm{O}_{3}-\mathrm{NO}_{x}$ hydrocarbon chemistry, 1. Model formulation, J. Geophys. Res., 103, 10713-10725, 1998.
Xu, L., Guo, H., Boyd, C. M., Klein, M., Bougiatioti, A., Cerully, K. M., Hite, J. R., Isaacman-VanWertz, G., Kreisberg, N. M., Knote, C., Olson, K., Koss, A., Goldstein, A. H., Hering, S. V., de Gouw, J., Baumann, K., Lee, S.-H., Nenes, A., Weber, R. J., and $\mathrm{Ng}, \mathrm{N}$. L.: Effects of anthropogenic emissions on aerosol formation from isoprene and monoterpenes in the southeastern United States, P. Natl. Acad. Sci. USA, 112, 37-42, https://doi.org/10.1073/pnas.1417609112, 2015.

Xu, W., Kuang, Y., Zhao, C., Tao, J., Zhao, G., Bian, Y., Yang, W., Yu, Y., Shen, C., Liang, L., Zhang, G., Lin, W., and $\mathrm{Xu}, \mathrm{X}$ : $\mathrm{NH}_{3}$-promoted hydrolysis of $\mathrm{NO}_{2}$ induces explosive growth in HONO, Atmos. Chem. Phys., 19, 10557-10570, https://doi.org/10.5194/acp-19-10557-2019, 2019.

Yabushita, A., Enami, S., Sakamoto, Y., Kawasaki, M., Hoffman, M. R., and Colussi, A. J.: Anion-Catalyzed Dissolution of $\mathrm{NO}_{2}$ on Aqueous Microdroplets, J. Phys. Chem. A, 113, 4844-4848, https://doi.org/10.1021/jp900685f, 2009.

Yang, X., Cox, R. A., Warwick, N. J., Pyle, J. A., Carver, G. C., O'Connor, F. M., and Savage, N. H.: Tropospheric bromine chemistry and its impact on ozone: A model study, J. Geophys. Res, 110, D2331, https://doi.org/10.1029/2005JD003244, 2005.

Ye, C., Zhou, X., Pu, D., Stutz, J., Festa, J., Spolaor, M., Tsai, C., Cantrell, C., Mauldin Iii, R. L., Campos, T., Weinheimer, A., Hornbrook, R. S., Apel, E., Guenther, A., Kaser, L., Yuan, B., Karl, T., Haggerty, J., Hall, S., Ullmann, K., Smith, J. N., Ortega, J., and Knote, C.: Rapid cycling of reactive nitrogen in the marine boundary layer, Nature, 532, 489-491, https://doi.org/10.1038/nature17195, 2016.

Ye, C., Zhou, X., Pu, D., Stutz, J., Festa, J., Spolaor, M., Tsai, C., Cantrell, C., Mauldin III, R. L., Weinheimer, A., Hornbrook, R. S., Apel, E. C., Guenther, A., Kaser, L., Yuan, B., Karl, T., Haggerty, J., Hall, S., Ullmann, K., Smith, J., and Ortega, J.: Tropospheric HONO distribution and chemistry in the southeastern US, Atmos. Chem. Phys., 18, 9107-9120, https://doi.org/10.5194/acp-18-9107-2018, 2018.

Zare, A., Romer, P. S., Nguyen, T., Keutsch, F. N., Skog, K., and Cohen, R. C.: A comprehensive organic nitrate chemistry: insights into the lifetime of atmospheric organic nitrates, Atmos. Chem. Phys., 18, 15419-15436, https://doi.org/10.5194/acp-18-154192018, 2018.

Zhang, L., Gong, S., Padro, J., and Barrie, L.: A size-segregated particle dry deposition scheme for an atmosopheric aerosol module, Atmos. Environ., 35, 549-560, 2001. 